\title{
KONSTYTUCJA FEDERACJI ŚRODKOWO-EUROPEJSKIEJ JAKO WYRAZ INTEGRACYJNEGO IDEALIZMU W BUDOWIE SYSTEMU REGIONALNEGO BEZPIECZEŃSTWA W MYŚLI POLITYCZNEJ POLSKIEGO WYCHODŹSTWA W XX WIEKU
}

Koncepcje integracji europejskiej pojawiały się wielokrotnie na przestrzeni wieków w pracach wielu polityków i myślicieli, wśród których nie zabrakło króla Stanisława Leszczyńskiego, promującego w 1748 roku (Memoriał o ugruntowaniu pokoju) unię kontynentalnych państw chrześcijańskich stojącą na straży bezkonfliktowego rozwiązywania sporów, jak również aktywnych dekady później, w okresie narastającego kryzysu Rzeczpospolitej lub podczas zaborów, wybitnych pisarzy, polityków, filozofów i ekonomistów: Stanisława Staszica (Myśli o równowadze politycznej w Europie), księcia Adama Czartoryskiego (Esej o dyplomacji), Józefa Marii Hoene-Wrońskiego (Metapolityka), Wojciecha Bogumiła Jastrzębowskiego (Traktat o wiecznym przymierzu między narodami ucywilizowanymi: konstytucja dla Europy), Stefana Buszczyńskiego (Upadek Europy). Po odzyskaniu przez Polskę niepodległości wyróżniała się promowana przez Józefa Piłsudskiego idea współpracy państw Międzymorza, która była odpowiedzią na rosyjskie i niemieckie zagrożenie ${ }^{1}$.

Dr RoBert ZAPART - Wydział Prawa i Administracji Uniwersytetu Rzeszowskiego; e-mail: robert.zapart@poczta.onet.pl

${ }^{1}$ K. ŁastawsKi, Od idei do integracji europejskiej, Warszawa 2003, s. 44-49. Z niezwykle obszernej literatury tego okresu warto wymienić: K. Grygajtis, Polskie idee federacyjne $i$ ich realizacja w XIX i XX wieku, Częstochowa 2001; T. KISIELEwsKi, Federacja Środkowo-Europejska. Pertraktacje polsko-czechostowackie 1939-1943, Warszawa 1991; M.S. WolaŃSKI, Europa Środkowo-Wschodnia w myśli politycznej emigracji polskiej w latach 1945-1975, Wrocław 1996; J. ŁAPTOS, Europa marzycieli. Wizje i projekty integracyjne środkowoeuropejskiej emigracji politycznej 19401956, Kraków 2012; F. Gross, Federacje i konfederacje europejskie. Rodowód $i$ wizje, Warszawa 1994; P. WandyCz, L. FrendL, Zjednoczona Europa, teoria i praktyka, Londyn 1965; Federalizm. Teorie i koncepcje, red. W. Bokajło, Wrocław 1998; Akcja niepodległościowa na terenie międzyna- 
Wybuch II wojny światowej ostatecznie zdyskredytował, odwołujący się do praw naturalnych i odwzorowywany w sformułowaniu „pokój przez prawo”, paradygmat idealistyczny. Wiarę w gotowość państw do negocjacji, szacunek dla prawa i reguł rządzących społecznością międzynarodową i przypisywanymi jej wartościami związanymi z moralnością i sprawiedliwością, zastąpiła skutecznie użyta dla osiągnięcia założonych celów siła. Nie oznaczało to jednak porzucenia projektów związanych z budową nowego porządku w stosunkach międzynarodowych, które miały wyłonić się po zakończeniu konfliktu. Zapoczątkowane jeszcze w 1939 roku w obozie alianckim dyskusje na temat przyszłej integracji Europy i jej bezpieczeństwa, zyskały na znaczeniu po odwróceniu się wcześniejszego sojuszu niemiecko-sowieckiego oraz po włączeniu się do wojny Stanów Zjednoczonych. Interesująco wypowiadali się z perspektywy jej środkowo-wschodniej części na przykład: David Davis (A Federated Europe), Ivor Jennings (A Federation for Western Europe) czy też prof. Julien Huxley (Democracy Marches). Dwaj pierwsi proponowali ograniczenie suwerenności państw członkowskich i przekazanie części tych uprawnień, na wzór Stanów Zjednoczonych, wyższym powołanym organom, natomiast trzeci zachęcał do skorzystania z doświadczeń Brytyjskiej Wspólnoty Narodów regulującej najważniejsze jej sprawy podczas cyklicznych konferencji imperialnych ${ }^{2}$. Wszystkie pojawiające się ówcześnie koncepcje można podzielić na trzy obecne w federalizmie paneuropejskim kierunki - konstytucyjne, regionalne i funkcjonalne, z których praktycznie każdy był obecny, aczkolwiek w różnym stopniu z uwagi na doświadczenia historyczne i wynikające z nich preferencje, w myśli politycznej polskiego wychodźstwa ${ }^{3}$. Najmniej kontrowersji wzbudzały propozycje utworzenia regionalnej wspólnoty, która nie byłaby związkiem suwerennych państw, ani też federacją, ale czymś pośrednim z jasno nakreślonymi i nieprzekraczalnymi granicami w zakresie podmiotowości jej członków ${ }^{4}$. Wszystkie wymienione koncepcje łączy trwały spór o kształt Europy Środkowo-Wschodniej oraz jej pozycję w systemie kontynentalnego i światowego bezpieczeństwa. Wiele nadziei, towarzyszącej pracom nad powojennym kształtem Europy Środkowo-Wschodniej

rodowym 1945-1990, red. T. Piesakowski, Londyn 1999; Warszawa nad Tamiza. Z dziejów polskiej emigracji politycznej po drugiej wojnie światowej, red. A. Friszke, Warszawa 1994; O nowy ksztalt Europy. XX-wieczne koncepcje federalistyczne w Europie Środkowo-Wschodniej i ich implikacje dla dyskusji o przyszłości Europy, red. J. Kłoczowski, S. Łukasiewicz, Lublin 2003; O jedność Europy. Antologia polskiej XX-wiecznej myśli europejskiej, oprac. S. Łukasiewicz, Warszawa 2007; A. BoRZYM, J. Sadowski, Polsce Ojcowie Europy, Warszawa 2007; A. Barabasz, Polacy i Polska wobec idei integracji europejskiej w latach 1915-1957, Toruń 2008.

2 J. Huxley, Democracy Marches, London 1941, s. 11-126; K. LASTAwsKi, Od idei, s. 88-89.

${ }^{3}$ K. Grygajtis, Polskie idee, s. 472.

${ }^{4}$ P. Wandycz, L. Frendl, Zjednoczona Europa, s. 44; T. Piszczkowski, Polska a Nowa Europa, Londyn 1942, s. 28-29. 
i jej pozycji w systemie kontynentalnego i światowego bezpieczeństwa, pokładano w Karcie Atlantyckiej (1941) i Deklaracji Narodów Zjednoczonych (1942). W tym duchu przygotowano najbardziej znany ówcześnie Akt Konstytucyjny Związku Polski i Czechosłowacji ${ }^{5}$. Warto jednak wyróżnić te mniej eksponowane, ale interesujące z uwagi na odmienne kierunki paneuropejskiego federalizmu koncepcje polskiego dyplomaty Anatola Muhltsteina (The United States the Central Europe) ${ }^{6}$, oraz aktywnego w Klubie Naddunajskim Jerzego Kuncewicza ze Stronnictwa Ludowego (Zadania i pozycja Polski w uktadzie powojennym) ${ }^{7}$. W tym duchu opracowano także w połowie 1943 roku, a zatem w okresie poprzedzającym konferencję w Teheranie i zajęcie obszarów Rzeczypospolitej przez Armię Czerwoną, projekt Konstytucji Federacji Środkowo-Europejskiej, który będzie przedmiotem poniższych rozważań naukowych ${ }^{8}$.

\section{PODŁOŻE IDEOLOGICZNE PROJEKTU}

Historia Starego Kontynentu, a szczególnie jego środkowo-wschodniej części wykazała, że pomiędzy prawem narodów do samostanowienia i niepodległości a realnymi możliwościami jego wyegzekwowania, szczególnie przez średnie i mniejsze, zachodziła widoczna rozbieżność. Wiązała je natomiast niejednokrotnie: wspólnotowość losów, tradycja i uczucia religijne, walka o wolność, związki cywilizacyjne z Zachodem, ustroje oparte o poszanowanie praw jednostki oraz

${ }^{5}$ Akt Konstytucyjnego Związku Polski i Czechosłowacji, w: T. KIsIELEwsKi, Federacja, s. 259267; J. SKodlarski, Epilog uktady Sikorski-Beneš. Z dziejów polsko-czechostowackich w latach 1939-1949, Łódź 1988; M. ORzeCHOwsKa, Czechostowacja w polskiej myśli politycznej w okresie II wojny światowej, w: Polska myśl polityczna XIX i XX wieku, t. I: Polska i jej sąsiedzi, Wrocław 1975; P. Wandycz, Próby stworzenia konfederacji polsko-czechostowackiej podczas drugiej wojny światowej, w: Władze RP na obczyźnie podczas II wojny światowej 1939-1945, red. Z. Błażyński, Londyn 1993; A.T. KolENDO, O idei federacji polsko-czechosłowackiej - polemicznie, „Dzieje Najnowsze" 1989, nr 2; Korespondencja w sprawie konfederacji polsko-czechostowackiej w latach 1940-1943, wyd. S. Stanisławska, „Studia z Najnowszych Dziejów Powszechnych” 4 (1963); P. MATUSAK, Polskie koncepcje integracyjne Europy Podziemnej 1939-1945, w: Państwo - ludowcy - myśl polityczna. Ksiega pamiątkowa ku czci prof. J. Jachyma, red. Z.J. Pietras, A. Wójcik, W. Paruch, Lublin 1999; J.R. SiELEZIN, Idea federacji polski-czechosłowackiej jako element gry politycznej w latach 1939-1943, w: Europa Środkowo-Wschodnia w polskiej myśli politycznej, red. M. Dymarski, J. Juchnowski, Wrocław 2004, s. 137-158; K. MochlıŃski, Polskie inicjatywy Federacji Europy Środkowo-Wschodniej, w: Akcja niepodległościowa na terenie międzynarodowym 1945-1990, red. T. Piesakowski, Londyn 1999, s. 143-165.

${ }^{6}$ A. Muhltstein, The United States the Central Europe, New York 1942.

${ }^{7}$ J. Kuncewicz, Zadania i pozycja Polski w uktadzie powojennym, Paryż-Londyn 1940.

${ }^{8}$ Archiwum Biblioteki Uniwersytetu Jagiellońskiego [dalej: ABUJ], sygn. 11840, Tezy konstytucyjne Federacji Środkowo-Europejskiej, k. 328. 
podobieństwo rozwoju gospodarczego i układów społecznych. Powyższe czynniki w sposób naturalny zatem determinowały ich działania na rzecz stworzenia regionalnego systemu bezpieczeństwa, który byłby podmiotową częścią projektu o podobnych celach. Tę jedność idei dostrzec można w kształcie dyskutowanych od traktatu wersalskiego do końca lat 30. XX wieku związkach suwerennych państw Europy Środkowo-Wschodniej, które miałyby zagwarantować równość praw wszystkich członków oraz poszanowanie praw jednostek w każdym z państw stowarzyszonych. Zadaniem powołanych w ramach porozumień traktatowych władz byłoby: prowadzenie wspólnie uzgodnionej polityki zagranicznej, rozporządzanie siłami zbrojnymi oraz wspieranie współpracy gospodarczej. Podstawą wdrożenia tak ogólnie zarysowanego projektu miała być wola narodów do decydowania o własnej podmiotowości oraz brak akceptacji dla zawieranych ponad ich głowami porozumień opartych na przemocy lub groźbie jej użycia. Uważano to co do zasady za niemoralne i nierealne do utrzymania w dłuższej perspektywie, nawet jeżeli akceptowała je przeważająca część ówczesnego świata polityki. Idealistyczny świat stanowił projekcję tego, czego pożądali, a co stawało się anachronizmem nieprzystającym do gwałtownie zmieniającej się rzeczywistości ${ }^{9}$.

Wybuch drugiej wojny światowej determinował konieczność przyśpieszenia prac nad formami integracji sąsiadujących ze sobą narodów Europy Środkowo-Wschodniej. Ich finałem miało być powołanie podmiotu liczącego ponad 100 milionów osób, z blisko dziesięcioma wyznaniami religijnymi, kilkunastoma językami i tyluż odmiennymi kulturami. Towarzyszyć temu miało przekonanie o skuteczności eliminacji lub ograniczenia nawarstwionych od wieków sporów pomiędzy tworzącymi go państwami o granice, pierwotne interesy oraz hierarchie celów i wartości. Jednak warunkiem przebudowy dotychczasowego systemu musiała być nie dobra wola elit i skuteczność dyplomatycznych zabiegów, ale realna możliwość dokonania głębokich przeobrażeń pojęć prawnych oraz poważne osiągnięcia w sferze obyczaju.

W świetle teorii polityki i prawa międzynarodowego Europa w pierwszej połowie XX wieku była uczestnikiem niezwykle niepokojących w kontekście jej przyszłości procesów i casusów, w tym: Paktu Czterech (1934), Monachium (1938), porozumienia sowiecko-niemieckiego (1939), a działania mocarstw alianckich w pierwszym okresie II wojny światowej przygotowywały ją na Teheran, Jałtę i Poczdam. Odrzucając wersalski idealizm akceptowano uzyskującą przewagę ponad prawem siłę, cofając rozwój ludzkości do dogmatu nieskrępowanej i nieograniczonej niczym suwerenności kilku mocarstw. Jedni widzieli w tym

${ }^{9}$ T. Łoś-NowaK, Stosunki międzynarodowe. Teorie - systemy - uczestnicy, Wrocław 2000, s. $42-43$. 
rywalizację o potęgę, a tym samym o przywództwo w świecie, inni natomiast wskazywali na anarchię będącą następstwem braku władzy nadrzędnej nad państwami i towarzyszącą temu niepewność co do zachowań innych podmiotów, skutkującą koniecznością samodzielnego dbania o własne bezpieczeństwo ${ }^{10}$. Najbardziej dotknięci następstwami zmian przedstawiciele średnich i małych państw mogli jedynie apelować o przywrócenie ładu w stosunkach międzynarodowych, którego częścią byłaby równość stron wobec prawa, a w ślad za tym odrzucenie bezkarności stosujących w sposób nieuprawniony siłę, a także odpowiedzialność przed organizacjami nadrzędnymi dysponującymi możliwościami zastosowania sankcji. Wszelkie układy i zobowiązania, by mieć moc wiążącą, nie mogły być „strzępem papieru” przekreślonym jednostronną decyzją poza wszelką procedurą, do tego niepociągającą za sobą negatywnych konsekwencji, a w skrajnym przypadku i siły w służbie przywracania prawa. To ostatnie, aby być faktycznie uznawanym, a nie tylko znoszonym lub narzuconym, winno pozostać kodyfikacją istniejącego stanu rzeczy, posiadać dostateczne oparcie w ustalonych obyczajach i praktyce międzynarodowej, a także w świadomości i przekonaniach społecznych. W tym kontekście polityczne układy regionalne, aby były całkowicie dobrowolne, musiały wypływać z uznanych norm moralności międzynarodowej, gwarantującej harmonijne współdziałania wielu stron.

Należałoby w tym miejscu przywołać kilka najważniejszych z nich. Po pierwsze, budująca zaufanie lojalność, pozbawiona cech oszustwa i utożsamiana z rzymską zasadą dotrzymywania umów (pacta sunt servanda). Po wtóre, umiar w realizacji własnych celów obciążonych nacjonalizmem i dążeniem do hegemonii. Po trzecie, wzajemna pomoc oparta o zdroworozsądkową i chrześcijańską doktrynę, która wspiera rozwiązywanie problemów jednego narodu przez drugi w myśl zasady mówiącej, że troski innych mogą się jutro stać naszymi. Brak reakcji czy też tolerancja niesprawiedliwości wobec słabszych i mniejszych podmiotów może zawierać w sobie groźbę na przyszłość dla biernego obserwatora. Po czwarte, odwzajemniany szacunek dla wolności, godności jednostek innego narodu, ich religii, dążeń do porządkowania wspólnoty według własnych reguł, a także niezależności dla odmiennych myśli, obyczajów i tradycji. Po piąte, nakaz działania w duchu sprawiedliwości, oparty o aprobatę ludzkiego sumienia. Po szóste, nakaz solidarności w budowie wspólnego dobra w powolnym procesie scalania się całej ludzkiej zbiorowości.

${ }^{10}$ J. WiĘCŁAWSKI, Teoria realizmu Hansa J. Morgenthaua, koncepcje, krytyka i znaczenie dla współczesnych stosunków międzynarodowych, Olsztyn 2014, s. 95-100; R. RYBARSKI, Siła i prawo, Warszawa 1936, s. 84-89. 
Przeniknięcie i zobiektywizowanie się powyższych zasad w świadomości narodów Europy Środkowo-Wschodniej było w idealistycznych prognozach przedstawicieli wychodźstwa częścią uświadamiającego przyszłych obywateli regionalnego związku procesu. Przy szerokiej samodzielności, jaką miały zachować tworzące go państwa, nieodzowne byłoby dostosowanie ich ustrojów i prawodawstwa do założeń i celów nowego podmiotu. Urzeczywistnienie programu jedności politycznej Europy Środkowo-Wschodniej wymagałoby wypracowania nowych norm współżycia międzynarodowego i wizji przeobrażeń wewnętrznych, których wzorców, niekoniecznie należałoby szukać w nieodległej przeszłości. Nie przesądzając odpowiedzi na podstawowe pytanie, federacja czy konfederacja, należało od początku przyjąć podstawy do dalszych dyskusji. Akceptację uzyskała forma wspólnoty, która z jednej strony możliwie w najmniejszym stopniu ograniczy suwerenne prawa państw czy ich grupy, a z drugiej, należycie zabezpieczy centralnym organom ustawodawczym i wykonawczym dostatecznie szeroki zakres uprawnień umożliwiających jej stabilizację wewnętrzną i godną pozycję zewnętrzną, określoną sformułowaniem power w stosunkach międzynarodowych. W przypadku powodzenia tegoż regionalnego projektu można byłoby mówić o początku nowej ery politycznej na Starym Kontynencie, kładącej prawdopodobnie kres niemiecko-rosyjskiej rywalizacji o jego środkową część, a także budującej podstawy światowego systemu bezpieczeństwa. $\mathrm{Z}$ nieco innej perspektywy, ale zachęcająco o wielostopniowej integracji Starego Kontynentu, wspominał w programie BBC w marcu 1943 roku brytyjski premier Winston Churchill, przedstawiając w nim ideę tworzenia Europy, która stanowiłaby strefę pośrednią między Stanami Zjednoczonymi i ZSRR realizującą wspólne cele polityczne, dysponującą odrębnymi siłami zbrojnymi oraz sądownictwem rozsądzającym spory pomiędzy państwami członkowskimi ${ }^{11}$. Jeszcze szerzej o integracji wypowiadali się uczestnicy Kongresu Paneuropejskiego w Nowym Jorku, przygotowując w 1943 roku Projekt konstytucji Stanów Zjednoczonych Europy ${ }^{12}$.

\section{INTEGRACJA KONTYNENTU W POLSKICH OCZEKIWANIACH}

Każde funkcjonujące w stosunkach międzynarodowych państwo na pierwszym miejscu stawia potrzeby i interesy egzystencjalne składające się na treść racji stanu, okazując jednocześnie innym podmiotom własne oczekiwania i żądania co do ich zachowań we wzajemnych relacjach. Szczególne miejsce zajmuje w nich wizja bezpieczeństwa oraz warunki nieskrępowanego rozwoju, które z uwagi na

\footnotetext{
${ }^{11}$ K. Łastawski, Od idei, s. 90; J. Łaptos, Europa, s. 52.

${ }^{12}$ K. ŁastawsKi, Od idei, s. 91.
} 
dynamikę zachodzących w świecie procesów są pochodną kilku czynników, w tym: położenia i historii państwa, jego miejsca wśród innych podmiotów, percepcji środowiska międzynarodowego oraz chęci i realnych możliwości wpływania na nie. Ukierunkowanie na osiągnięcie własnych celów może się dokonywać także poprzez interesy koegzystencjalne, które mogą dzięki przynależności do grupy państw lub współpracy z nią pomóc zrealizować narodowe aspiracje i osiągnąc zewnętrzne uznanie. Szanse powodzenia zależą od stopnia zbieżności celów, koncentracji działań początkowych na poziomie kręgów regionalnych, kontynentalnych i światowych, jak również od trafności rozpoznania perspektyw re- lub ewolucji w stosunkach w każdej z wybranych sfer $^{13}$. Do tych podstawowych zasad próbowały dostosować się środowiska polskiego wychodźstwa. Zjednoczona Europa jawiła się im od początku, jako wymagający legitymizowania podzielanych wspólnie z innymi cywilizacyjnych wartości i kulturowo przyciągający projekt. Miała to być w założeniach wspólnota, w której: zrealizują się idee solidarności społecznej, można uzyskać godną rekompensatę za sojuszniczą zdradę i obcy najazd, otrzymać wsparcie na rzecz zniwelowania odczuwalnych po wojnie różnic gospodarczych i społecznych, podziela się podobne poczucie sprawiedliwości oraz ocenia poziomy zewnętrznego zagrożenia. To zatem miejsce, gdzie faktycznie, a nie iluzorycznie, obiektywizują się normy demokratycznego państwa prawnego i rządzące relacjami międzyludzkimi nastawione na pozytywną współpracę motywacje, oraz wspólnie z innymi kształtuje się model społeczeństwa obywatelskiego opartego na chrześcijańskich wartościach. Istotna również była dla nich przejrzystość procesu podejmowania najważniejszych decyzji na wszystkich szczeblach bądź powoływanego związku państw, która ograniczyłaby w przyszłości problemy z: partycypacją społeczną, rywalizacją pomiędzy narodami na niektórych płaszczyznach, a także zmniejszałaby zagrożenie spowodowane ewentualną utratą tożsamości narodowej. Ta ostatnia, dzięki wzajemnej komunikacji, będącej pierwszą formą wewnętrznej integracji oraz elementem obywatelskiej i związkowej solidarności, stanowiła największą przeszkodę w długotrwałym procesie ujednolicania wspólnych wartości.

Najważniejszym wyzwaniem i zobowiązaniem stojącym przed elitami wychodźczymi było zatem zaprojektowanie akceptowalnego przez konstytucyjną większość systemu politycznego, który stworzyłby maksymalne możliwości internalizacji norm prawnych pielęgnujących naszą kulturę ugody z innymi i minimalizujących potrzebę zastosowania ewentualnego przymusu. Z perspektywy ustrojowej wyłaniał się kolejny problem związany z jego strukturą. Czy miał to być związek państw, w którym poszczególne kraje zachowują swoją suwerenność, czy też państwo związkowe, z koniecznością funkcjonowania organów nadrzędnych. Optowano

${ }^{13}$ J. KUKUŁKA, Teoria stosunków międzynarodowych, Warszawa 2000, s. 222-223. 
za pierwszym rozwiązaniem, ale $\mathrm{z}$ jednoczesnym takim ukonstytuowaniem się władz, by były one w stanie zapobiegać negatywnym konsekwencjom nieuniknionych rozbieżności pomiędzy stronami, w tym przeciwdziałać spodziewanym tendencjom odśrodkowym. Nie było natomiast wątpliwości co do ich kompetencji, które winny obejmować: reprezentację zewnętrzną, politykę zagraniczną, obronę, a także sprawy gospodarcze, komunikacyjne oraz skarbowe związane ze wspólnotową aktywnością. Sprzeciwu również nie zgłaszano do jego republikańskiego i antytotalitarnego charakteru ${ }^{14}$.

Postulaty utworzenia związku odnotowujemy w wypowiedziach ówczesnego premiera gen. Władysława Sikorskiego oraz ministrów jego gabinetu, które powiązano z globalną reformą stosunków międzynarodowych, których częścią była aprobata dla idei budowy wielostopniowego systemu regionalnego bezpieczeństwa, bazującego na pax slavica zamiast na pax sovietica i pax germanica ${ }^{15}$. Doświadczenia historyczne podpowiadały emigracyjnym ekspertom, że równowagę w Europie można było utrzymywać do czasu, jak długo jej „strefa środkowa” nie była polityczną i militarną próżnią pomiędzy wykazującymi agresywne działania Niemcami i Rosją, a także nie występowało rozbicie na kilka mniejszych państw, lecz istniał alternatywny i gwarantujący względną stabilizację podmiot, określany mianem regionalnego mocarstwa, w którego granicach znajdywały one oparcie. Takimi krajami była Rzeczpospolita do 1772 roku, napoleońskie „sklepienie Europy”, oraz do 1918 roku Monarchia Austro-Węgierska. Otoczona agresywnymi sąsiadami lub skłóconymi między sobą państwami powersalska Polska, nie była w stanie sama stawić czoła w 1939 roku dwóm zjednoczonym przeciwko niej potęgom. Jej upadek pociągnął za sobą wkrótce utratę podmiotowości przez kilka kolejnych krajów, co skutkowało rozkładem dotychczasowego światowego systemu bezpieczeństwa. Przebywające na uchodźstwie władze II RP podjęły w 1940 roku prace studyjne nad jego przywróceniemem, opierając się na bliższej współpracy z innymi, doświadczonych podobnymi problemami przedstawicielami okupowanych państw. Za najbardziej obiecujący uznano plan utworzenia federacji polsko-czechosłowackiej, która mogła zostać rozszerzona o bliźniaczą bałkańską, tworząc jeden związek do Bałtyku po Morze Egejskie. Dla Polaków oraz ich środkowoeuropejskich przyjaciół postulat zjednoczenia regionu pozostawał programem rekonstrukcji obszaru, gdzie ponad 100 milionów osób, wyposażonych we wspólną organizację polityczną i wojskową oraz integrującą się funkcjonalnie gospodarkę,

${ }^{14}$ Zasady Aktu Konstytucyjnego Polski i Czechosłowacji, w: T. KIsIELEwsKi, Federacja, s. 259268; R. ZAPART, Wtadze RP na Uchodźstwie o projekcie polsko-czechostowackiej wspótpracy w latach osiemdziesiatych XX wieku, „Studia Polonijne” 35 (2014), s. 48.

${ }^{15}$ F. Gross, Crossroads of Two Continents. A Democratic Federation of East-central Europe, New York 1945, s. 1-3; M.S. WolAŃsKI, Europa, s. 111. 
gwarantowało definitywne rozwiązanie problemów europejskiego bezpieczeństwa ${ }^{16}$. Oceniano, że będzie musiało dojść do takich rozwiązań, gdyż:

a) państwa regionu niewiele dzieli politycznie, natomiast łączy je wspólne zagrożenie ze strony Niemiec lub/i Rosji, co w przypadku polskiej doktryny obronnej łączyło się z wcześniejszą koncepcją dwóch przeciwników ${ }^{17}$;

b) zainteresowane podmioty rozumieją, iż działając wspólnie mogą lepiej wykorzystać dla siebie gospodarcze znaczenie tego obszaru, dopełniając braki zachodniej Europy;

c) zarysowująca się integracja Zachodu będzie wymagała wolnej Europy Środkowo-Wschodniej, jako pewnej organizacyjnej przeciwwagi do kolejnego kroku, pełnej integracji europejskiej;

d) zaistnieje możliwość likwidacji sowieckiego imperium, a związek, czy też związki państw środkowej i wschodniej Europy, będą naturalnymi i politycznie najbardziej wskazanymi łącznikami między Zachodem a Eurazją.

\section{PODSTAWY POLITYCZNO-PRAWNE FEDERACJI ŚRODKOWO-EUROPEJSKIEJ}

Najbardziej rozpoznawalnym w okresie II wojny światowej był projekt federacji polsko-czechosłowackiej, którego twórcy w części wzorowali się na dostępnych w federacjach i konfederacjach rozwiązaniach prawnych, szczególnie amerykańskich i szwajcarskich ${ }^{18}$. Z perspektywy politycznej, społecznej i gospodarczej uznawano, że będzie to z czasem dobra płaszczyzna do dalszych rozmów na temat integracji, w tym na przykład z planowaną równolegle Unią Bałkańską. Blisko współpracujący z premierem Władysławem Sikorskim Józef Retinger oraz pracownicy Departamentu Stanu USA potwierdzali później, że zakładano w pełni funkcjonalną w sferze gospodarki federację złożoną, poza Polską i Czechosłowacją, z krajów bałtyckich, Węgier, Rumunii i sfederowanej Jugosławii ewentualnie Austrii1 ${ }^{19}$. Po

${ }^{16}$ Szerzej np. w: A. BRZEZIŃsKI, Kwestia powojennej organizacji bezpieczeństwa $w$ polityce zagranicznej Rządu RP na Uchodźstwie 1939-1945, Łódź 1999; C. SKUZA, Bezpieczeństwo zewnętrzne państwa w programach i działaniach polskich polityków (1939-1955), Szczecin 2012, s. 23-58.

${ }^{17}$ C. SkuzA, Bezpieczeństwo, s. 41-42.

${ }^{18}$ Ł. LewKowicz, Idea polsko-czechostowackiego związku państwowego w działalności politycznej obozu emigracyjnego (1939-1945). Zarys problematyki, w: Europejskie inspiracje myśli politycznej w Polsce od XIX do XXI wieku. Recepcja - kontynuacja - interpretacja, red. E. Maj, A. Dawidowicz, Ł. Lewkowicz, A. Szwed, Lublin 2013, s. 409; T. Kisielewski, Federacja, s. 259 n.

19 J. Pomian, Józef Greting. Życie i pamiętniki pioniera Jedności Europejskiej, Warszawa 1994, s. 99; J. Pomian, Józef Retinger - życie i pamiętniki „szarej eminencji”, Warszawa 1990, s. 172; J. ŁaPtos, Europa, s. 31, 46. 
części odpowiada powyższym założeniom, nie wolny od wad w zakresie prawa, projekt Konstytucji Federacji Środkowo-Europejskiej, który powstał w następstwie prac międzynarodowego zespołu intelektualistów, ekonomistów oraz prawników wchodzących w skład specjalnej Komisji przy Środkowo-Europejskim Klubie Federalnym w Londynie ${ }^{20}$. Niewykluczone, że był on równocześnie pokłosiem jej szerszej współpracy z utworzonym w Nowym Jorku w 1941 roku Central and East European Planning Board, cenionego międzynarodowego zespołu z udziałem przedstawicieli polskiego rządu, przygotowującego rozwiązania dotyczące przyszłej środkowoeuropejskiej federacji ${ }^{21}$. Ten pozostawiony do dalszych prac materiał miał pomóc w przyszłości Sikorskiemu w przekonaniu własnego zaplecza politycznego do integracji oraz ograniczyć uprzedzenia czeskich i słowackich elit emigracyjnych z prezydentem Edwardem Benešem na czele do szerszej grupy uczestników projektu. Jednak zasadniczym elementem ograniczającym jego decyzyjność i konstytuującym taką lub inną formę wspólnoty, była zbyt daleko idąca niepewność w zakresie kierunków rozwoju działań wojennych. Według Feliksa Grossa, rząd polski przewidywał w 1942 roku w przypadku inwazji alianckiej na Bałkanach ogłoszenie na pierwszych wyzwolonych tam terenach decyzji o utworzeniu konfederacji Europy Środkowo-Wschodniej ${ }^{22}$. Zanim to miało nastąpić, należało zmierzyć się z podejrzeniami, czy też obawami, mniejszych państw przed potencjalnymi stratami, jakie mogłyby one ponieść w przypadku realizacji projektu Międzymorza. Część z nich udało się rozproszyć w projekcie Konstytucji Federacji Środkowo-Europejskiej, która jest przedmiotem tych analiz opartych o następujące uszeregowanie: 1. Problemy konstytucyjne, 2. Polityka zagraniczna, 3. Polityka bezpieczeństwa i obrony, 4. Polityka gospodarcza.

Z perspektywy konstytucyjnej zakładano powołanie unii narodów, która tworząc państwo federalne dysponowałaby przekazanymi organom związkowym częściami ich suwerenności. Jej członkiem mógł zostać każdy kraj położony na obszarze pomiędzy Adriatykiem, Bałtykiem, Morzem Czarnym oraz Rosją i Niemcami, spełniający jednocześnie wymogi demokratycznego państwa prawnego. Te ostatnie miały zostać wcześniej odzwierciedlone w zapisach krajowych konstytucji i obejmować: gwarancje wolności osobistych, prawo do zrzeszenia się i zgromadzeń, wolność słowa i druku, niezależność sądownictwa oraz parlamentarną kontrolę rządów przez przedstawicieli narodu. Po powołaniu unii każdy kolejny spełniający powyższe warunki podmiot mógłby zostać do niej przyjęty po akceptacji wyra-

${ }^{20}$ ABUJ, sygn. 11840, k. 328.

${ }^{21}$ G. WitKowski, Józef Retinger, polski inicjator integracji europejskiej, Warszawa 2000, s. 65-66; F. Gross, Federacje, s. 47. W Radzie Planowania zasiadał z ramienia Polski minister Jan Stańczyk, a później Sylwin Strugaczka.

${ }^{22}$ F. Gross, Federacje, s. 48. 
żonej w procedurze kwalifikowanego głosowania przez jej ustawodawcze organy, a następnie potwierdzonej przez parlamenty krajowe zwykłą większością głosów, przy dopuszczalnym sprzeciwie najwyżej dwóch członków wspólnoty ${ }^{23}$. W świetle powyższych wymogów widoczne było uprzywilejowanie państw założycielskich, co w pewien sposób ograniczało dostęp kolejnym zainteresowanym. Była to zatem swoista premia, zachęcająca już na początku do działań integracyjnych, odbierana także przez postronnych jako poważna próba korekty obowiązujących ówcześnie zasad tworzenia nowych podmiotów prawa międzynarodowego. $Z$ uwagi na różnicę potencjałów pomiędzy Polską a pozostałymi krajami Małej Europy można dostrzec także pewne niewielkie analogie do powestfalskiego systemu kolektywno-paternalistycznego, a także do współczesnych procedur przyjęcia nowych krajów do Unii Europejskiej ${ }^{24}$.

Na zewnątrz Unia miała występować jako jednolita całość, natomiast wewnątrz zobowiązywała się zachować pełną swobodę indywidualnego rozwoju poszczególnym narodom, przy maksymalizowanej wymianie wartości kulturowych i zdobyczy cywilizacyjnych, którego granicą miało być sukcesywnie definiowane wspólne dobro. $Z$ perspektywy ustrojowej dysponowałby kompetencjami w następujących obszarach: reprezentacja zewnętrzna, polityka zagraniczna, obronność, gospodarka, sprawy społeczne (służba zdrowia oraz ujednolicany z czasem system wychowania i oświaty). Dla zabezpieczenia pełnej swobody jej członków w kompetencjach ich władz krajowych miały pozostać: szczegółowe decyzje dotyczące modelu politycznego, administracja wewnętrzna, organizacja życia gospodarczego, wojsko narodowe, sądownictwo oraz życie kulturalne i oświatowe. Zapisy ustaw zasadniczych państw członkowskich nie mogły być sprzeczne z federalnym Aktem Konstytucyjnym ${ }^{25}$. Naczelnymi organami Unii miały być: przewodniczący („głowa państwa”), Rada Stanu, Rząd Federalny oraz Parlament Federalny złożony z Kongresu i Senatu. Tytuł oraz status ustrojowy „głowy państwa” miał zostać ustalony w przyszłości przez pierwsze Konstytucyjne Zgromadzenie Kongresu (Izby poselskiej) i Senatu. Izba niższa miała zostać powołana na pięcioletnią kadencję $\mathrm{w}$ drodze wyborów pięcioprzymiotnikowych z krajów należących do wspólnoty w liczbie odpowiadającej jednemu posłowi na ustaloną przez państwa założycielskie grupę wyborców. Izba wyższa składałaby się z senatorów wybranych $\mathrm{w}$ równej liczbie z każdego kraju, z tym że nie mogło być ich więcej, niż

${ }^{23}$ Tamże.

${ }^{24} \mathrm{O}$ miejsce lidera rządów uchodźczych zabiegał, pragnąc wzmocnić pozycję Rzeczpospolitej w tej części Europy i nawiązać do sukcesu Jagiellonów, gen. Władysław Sikorski, zob. A.M. BRzEZIŃSKI, Kwestia powojennej organizacji, s. 31.

${ }^{25}$ ABUJ, sygn. 11840, k. 329. 
wynosi połowa liczby posłów do Kongresu ${ }^{26}$. Liczba ludności Polski dawałaby jej w niższym organie ustawodawczym poważne uprzywilejowanie, które trudno byłoby niwelować bez zbudowania pokaźnej przeciwnej jej koalicji lub po odpowiednim zwiększeniu liczby członków Unii z odpowiednim potencjałem wyborców. Pewne ograniczenie stanowiłby Senat, wsparty kompetencjami „głowy państwa”, który w porozumieniu z Radą Stanu (przewodniczący Kongresu i Senatu oraz marszałkowie sejmów i senatów krajów członkowskich) mógł wetować ustawę, a jej odrzucenie wymagałoby kwalifikowanej większości 3/5 głosów izby niższej. Podobna procedura obowiązywałaby w przypadku odrzucania ustaw przez Senat lub wprowadzenia doń poprawek. Zakres kompetencji obydwu izb parlamentu obejmował: ustawodawstwo ogarniające funkcjonowanie władz federalnych, uchwalanie okresowych planów gospodarczych i budżetu unii, udzielanie rządowi absolutorium $\mathrm{z}$ wykonania tego ostatniego, ratyfikowanie umów międzynarodowych (jeżeli takowe tego wymagały), zgłaszanie votum nieufności wobec całego rządu lub jednego z ministrów federacji. Inicjatywa ustawodawcza przysługiwać miała Kongresowi oraz rządowi federalnemu. Ten ostatni był przewidziany jako organ wykonawczy, w którym żaden kraj nie mógłby mieć więcej niż połowę ogólnej liczby jego członków, przy czym każdy musiałby mieć przynajmniej jednego przedstawiciela $^{27}$.

Na podkreślenie zasługuje konieczność powołania odpowiedzialnych za wymienione i związane z kompetencjami federacji obszary odpowiedzialności konstytucyjnych ministrów. Nie ustanowiono jednak wymogu ograniczenia dostępu silniejszym państwom do niższych, ale istotnych stanowisk, co w pewien sposób mogłoby utrudnić realny wpływ mniejszych członków federacji na władzę wykonawczą. W projekcie zakładano również utworzenie Federalnego Trybunału Konstytucyjnego, którego głównym zadaniem miało być rozstrzyganie sporów w zakresie zgodności ustaw, rozporządzeń oraz zarządzeń wspólnotowych i krajowych z Aktem Konstytucyjnym, a także innych kompetencyjnych, w tym pomiędzy Unią a jej krajami lub pomiędzy nimi. Uzupełniał sądownictwo Federalny Trybunał $\mathrm{Stanu}^{28}$. Nie odnotowujemy w przywoływanych tezach konstytucyjnych odniesień do trudnych zagadnień narodowościowych krajów członkowskich, jednakże sygnalizowane ujednolicenie wychowania i oświaty świadczy o poważnym metodologicznym zainteresowaniu tym zagadnieniem. Zaprezentowany podział kompetencji sprawiał ogólne wrażenie spójnych, ale nie pozbawionych problemów i wyzwań związanych z wypracowaniem kompromisu w ramach grupy łączonych na dwóch

\footnotetext{
26 Tamże, k. 333.

27 Tamże, k. 331.

28 Tamże, k. 335.
} 
szczeblach kompetencji, których bardzo wyraźnie nie rozdzielono, pozostawiając to ustawodawstwu nowych wspólnotowych organów.

Wyłączną domeną władz Unii pozostawała polityka zagraniczna, przy czym na wniosek państwa członkowskiego mogły one w imieniu kraju lub ich grupy negocjować także umowy dotyczące zindywidualizowanych interesów, co w założeniu miało im zapewnić lepszą pozycję negocjacyjną wobec podmiotów zewnętrznych. W przypadku umów wspólnotowych (przewidujące stałą współpracę zagraniczną, zaciąganie kredytów zewnętrznych, traktaty handlowe lub inne specjalne, jak na przykład transportu powietrznego i lądowego) wymagały one przed wejściem w życie ratyfikacji Parlamentu Federalnego, przy czym te dotyczące zmian granic dodatkowo parlamentów krajów, które je dotyczą. Interesującym rozwiązaniem z perspektywy ewentualnych nagłych zagrożeń dla bezpieczeństwa zewnętrznego, „kiedy interes Unii mógłby być przez zwłokę narażony na szkodę”, przedstawiały się kompetencje „głowy państwa”, która na wniosek Rządu Federalnego i za kontrasygnatą Rady Stanu mogła czasowo drogą dekretu wprowadzić w życie wszystkie lub niektóre ich postanowienia ${ }^{29}$. Do niej także należało reprezentowanie Unii na zewnątrz, mianowanie i odwoływanie na wniosek Rządu Federalnego ambasadorów oraz zawierania umów międzynarodowych ${ }^{30}$. Polityka zagraniczna była realizowana przez ministra Rządu Federalnego oraz podległe mu wspólnotowe struktury dyplomatyczne, w skład których winni być powoływani, jednakże bez ustalonej procedury, obywatele wszystkich krajów członkowskich.

Polityka bezpieczeństwa i obrony stanowiła jedną z kluczowych spraw dla całej projektowanej federacji, której jednym z przejawów była przywoływana wcześniej możliwość tymczasowego wprowadzenia w życie w przypadku zewnętrznego zagrożenia nieratyfikowanych przez Parlament Federalny umów międzynarodowych. Ten wprawdzie niesprawdzony ówcześnie mechanizm odstraszenia mógł polegać na przykład na możliwości zawarcia okazjonalnej umowy, obejmującej: wspólne działania zbrojne przeciwko potencjalnym agresorom, dostawy odpowiedniego sprzętu wojskowego lub uruchomienia innych aktywów zniechęcających drugą stronę do rozpoczęcia lub kontynuowania agresywnych kroków, zwiększając teoretycznie tym samym szanse wspólnoty na skuteczną obronę ${ }^{31}$. Co do zasady zapewniać ją miały „Siły Zbrojne Unii oraz wszystkie inne siły i środki, dające się jej uzyskać dla utrzymania niepodległości i integralności”’32. Ten nieostry zapis

\footnotetext{
${ }^{29}$ Tamże, k. 335-336.

${ }^{30}$ Tamże, k. 330.

${ }^{31}$ Analiza porównawcza koncepcji integracji Europy Środkowo-Wschodniej z perspektywy doktryny bezpieczeństwa, w tym organów odpowiedzialnych za jej realizację, będzie przedmiotem odrębnej publikacji.

${ }^{32}$ ABUJ, sygn. 11840, k. 337.
} 
oznaczał jednak pełną jedność kierownictwa i decyzji w czasie wojny w rękach „głowy państwa" oraz ciągłość przygotowań do niej, za które był konstytucyjnie odpowiedzialny Rząd Federalny z kanclerzem (premierem) na czele. Ten ostatni korzystać miał z doradztwa Federalnej Rady Obrony, złożonej z przedstawicieli krajów członkowskich ${ }^{33}$. Ujednolicenie systemu dowodzenia siłami wspólnoty, przy zachowaniu równoczesnej autonomii poszczególnych rodzajów broni oraz wojsk narodowych, sprzyjało budowie potencjału obronnego. Jego integralną częścią pozostawały: uzupełniający się wzajemnie przemysł zbrojeniowy, stosunkowo dobre skomunikowanie liniami kolejowymi, naturalne granice obrony, a przy założeniu, że mogła ona liczyć w ramach rozszerzenia o wszystkie kraje Międzymorza, ponad $100 \mathrm{mln}$ mieszkańców, z których grona można było powołać liczącą się u potencjalnego przeciwnika liczbę żołnierzy i oficerów.

Rozwój gospodarczy Unii, jak również standaryzowanie dóbr według zasad planowości na podstawie przyjętych przez Parlament Federalny w formach ustawy założeń, stanowiły klucz bezkonfliktowej współpracy pomiędzy krajami członkowskimi oraz innymi podmiotami zewnętrznymi. Ich opracowanie następowało w rządowym porozumieniu z Federalną Izbą Gospodarczą, która miała reprezentować opiniujące projekty zmian samorządy gospodarcze oraz zawodowe. Przyjęte federalne plany gospodarcze miały stanowić wsparcia dla tych tworzonych przez poszczególne państwa, przy czym po ich uchwaleniu, te na szczeblu niższym nie mogły pozostać z nimi sprzeczne ${ }^{34}$. Unia stanowiła jednolity obszar celny, podlegający federalnej administracji. Kraje członkowskie miały prowadzić według przyjętych rozwiązań wspólną rozbudowę sieci komunikacyjnych, ujednolicić politykę tranzytową oraz pocztową, wspólnie administrować portami, żeglugą morską i rybołówstwem, przy czym te posiadające wybrzeże miały obowiązek uwzględnić interes całej Unii, a jego pozbawione - popierać interesy morskie, włącznie z prawem do własnej bandery ${ }^{35}$. W powyższych zamiarach nawiązywano do istniejących od 1931 roku zaczątków aranżowanego z inicjatywy Polski, a obejmującego Czechosłowację, Węgry, Rumunię i Bułgarię, bloku rolniczego środkowo-wschodniej Europy, którego celem było zharmonizowanie wzajemnej polityki eksportowej produktów wrażliwych ${ }^{36}$.

W ocenie ówczesnych brytyjskich analiz ekonomicznych region z ludnością liczącą pond $100 \mathrm{mln}$ mieszkańców byłby postrzegany jako pierwszorzędny rynek dla ich towarów i usług, ze względu na malejący eksport do dążących do samowy-

\footnotetext{
${ }^{33}$ Tamże, k. 337-338.

${ }^{34}$ Tamże, k. 338-339.

35 Tamże, k. 340.

${ }^{36}$ T. Piszczkowski, Polska, s. 37.
} 
starczalności dominiów. Świadczyło to zatem o właściwym kierunku rozważań na temat postępującej na bazie funkcjonalizmu współpracy gospodarczej, którą później podążyły kraje zachodnie ${ }^{37}$. Poważna unifikacja następowała również w polityce finansowo-walutowej i skarbowej. Wprawdzie każdy kraj miałby prawo posiadać własny bank emisyjny i walutę, to jednak zakładano ograniczające ich samodzielność stałe kursy rozliczeń, a także przewidywano obowiązek koordynowania polityki emisyjnej i kredytowej z federalnym sekretarzem stanu odpowiedzialnym za sprawy gospodarcze. Docelowo zamierzano po ustabilizowaniu kursu walut krajowych wprowadzić jedną wspólną ${ }^{38}$.

Elementem wskazującym na pozostawienie w ręku państw członkowskich pewnego zakresu suwerenności był ustrój gospodarczy, przy czym jego wewnętrzne ustawodawstwo musiało podlegać skoordynowaniu z unijnym w przypadku dziedzin wpływających ujemnie na rozwój całej wspólnoty. Podobnie projektowano z ustawodawstwem socjalnym, które miało zapewnić interesy ubezpieczonych oraz osiągnąć jednakowe obciążenia produkcji z tytułu świadczenia pracy ${ }^{39}$. Koordynowaniem polityki skarbowej zajmował się sekretarz stanu skarbu Unii, którego zadaniem było przygotowanie wspólnotowego budżetu oraz zarządzanie dochodami i wydatkami. $\mathrm{Z}$ tych ostatnich finansowano zadania uznane za szczególnie ważne dla jej rozwoju w obszarach gospodarczo niedoinwestowanych. Unia miała dysponować własnymi dochodami, aczkolwiek nie określono ich pochodzenia i wysokości, oraz parytetowymi dopłatami krajów członkowskich. W polityce skarbowej zmierzano do skoordynowania systemów podatkowych, aby osiągnąć wyrównanie obciążeń, zarówno z podatków pośrednich, jak i bezpośrednich, uwzględniając realne warunki produkcji oraz rzeczywistą zdolność płatniczą państw członkowskich ${ }^{40}$.

W sferze spraw społecznych, istotnych dla budowy potencjału wspólnoty, należy wyróżnić i pozytywnie ocenić próby ujednolicania szkolnictwa wszystkich szczebli, określenia minimalnych standardów opieki społecznej, służby zdrowia oraz wzmocnienia oddziaływania wspólnych wzorców kultury przy poszanowaniu tożsamości narodowej. Tymi ostatnimi miała się zajmować Federalna Izba Kultury, złożona z przedstawicieli poszczególnych państw ${ }^{41}$. Istotnym wsparciem dla wymiany kulturowej była propozycja ustanowienia języka angielskiego wspólnym językiem urzędowym na poziomie federalnym, ale na równi z innymi językami narodowymi. Równie ważne, wręcz zasadnicze dla budowania zrozumienia wewnętrznego wspólnoty i siły jej oddziaływania, było dodatkowe nabywane obywa-

\footnotetext{
${ }^{37}$ J. LAPTOS, Europa, s. 75.

${ }^{38}$ ABUJ, sygn. 11840, k. 341.

39 Tamże.

40 Tamże, k. 342.

${ }^{41}$ Tamże, k. 343.
} 
telstwo Unii oraz pełna swoboda ruchu osobowego i osiedlania się w jej graniach z pominięciem osób narodowości rosyjskiej i niemieckiej, co do których kraje członkowskie zastrzegły sobie swobodę podejmowania decyzji ${ }^{42}$. Nie należałoby traktować tego rozwiązania jako wyłącznie formy dyskryminacji i bezpośrednią pochodną wojny i okupacji, ale raczej analizować w kategoriach dotychczasowych negatywnych doświadczeń z państwami wspierającymi swoje mniejszości, ingerując tym samym w prawa sąsiadów.

Przedstawione wyżej podstawy ustrojowe planowanej wspólnoty stanowily element funkcjonalnego łańcucha kolejnych, merytorycznie pogłębionych, dyskusji, chociażby nawet nad przepisami temporalnymi, które musiałyby zostać przyjęte, zanim cały projekt uzyska po zakończeniu wojny społeczną akceptację obywateli państw członkowskich, wyrażoną na przykład w postaci obowiązkowych referendów. $Z$ pewnością poważnym wyzwaniem byłoby ich przekonanie co do konieczności zrzeczenia się na rzecz innego podmiotu części swych suwerennych praw w czasie, gdy oni dopiero by je odzyskiwali po latach okupacji lub zależności. W tym kontekście przeprowadzenie zmian w poszczególnych ustawach zasadniczych byłoby tylko „technicznym” problemem. Jeśli dołączymy do tego niewyartykułowane spory narodowościowe i graniczne, to widać, że projekt jest wyłącznie, wyprzedzającą alternatywne rozwiązania lansowane przez prowadzące wojnę mocarstwa, ideą wymagającą precyzyjnych i przełamujących wiele barier doprecyzowań i uzgodnień. Ich wyeliminowanie lub ograniczenie mogłoby się okazać jednak atrakcyjniejsze niż ponowna utrata podmiotowości.

Można się również zastanawiać, czy istniała możliwość prawnego rozgraniczenia między promowanymi przez innych, w tym do 1943 roku przez Churchilla, regionalnymi federacjami, a także pomiędzy nimi i organizacją światową. Oczywiście wyczerpującej odpowiedzi można byłoby udzielić analizując ich struktury i kompetencje, niemniej jednak wiele wskazywało ówcześnie na możliwość formalnego współdziałania. Zarówno państwa niestowarzyszone, jak i ugrupowania regionalne, stanowić miały w stosunku do zrzeszenia kontynentalnego jednostki podstawowe o podobnych prawach i zobowiązaniach. Można zatem wnioskować, że łatwiejsze byłoby rozgraniczenie kompetencji pomiędzy podmiotami regionalnymi i wspólnotą kontynentalną, niż pomiędzy tą drugą a zrzeszeniem światowym. Przy rosnącym potencjalnie znaczeniu tej ostatniej, niewątpliwie dążyłaby ona do ześrodkowania w swoich rękach wszystkich agend rozwiązujących spory i zapobiegających konfliktom, kumulowała prawa do stosowania sankcji oraz posiadania i rozporządzania międzynarodową siłą zbrojną. $Z$ tychże powodów utrzymanie żywotnej pośredniej, dwustopniowej organizacji kontynentalnej mogłoby natrafić na poważne trudności

42 Tamże, k. 344. 
podmiotowe w przyszłości. Także stopień skomplikowania spraw budził obawy co do skuteczności powodzenia omawianego projektu.

Alternatywne propozycje, również bazujące na paneuropeizmie, odnajdujemy w pracy polskiego dyplomaty Anatola Mulsteina, związanego niegdyś z kręgami bliskimi Józefowi Piłsudskiemu oraz wolnomularstwem. Odrzucił on jednak myśl o tworzeniu dla związku państw projektu konstytucji obawiając się, czy w odróżnieniu od sfederowanych i wykazujących tendencje dośrodkowe Stanów Zjednoczonych Ameryki Północnej uda się w Europie Środkowo-Wschodniej zrealizować projekt, przy tak silnie obecnych przeciwnych trendach, gdy należy „zrzeszyć populacje posługujące się różnymi językami, posiadające różne kultury i tradycje”"43. Dla niego myśl polityczna pierwszych „Ojców Konstytucji” była znacznie lepsza od sentymentów kierujących narodem amerykańskim. Tej anglosaskiej - jak tłumaczył - grupie kulturowej, posługującej się tym samym językiem, pielęgnującej podobne źródła duchowe, przyzwyczajonej do tych samych instytucji upominawczych i form prawnych, a zatem ,pierwotnej substancji” wielkiego zjednoczonego narodu, wystarczyło nadać mądre i skuteczne instytucje konstytucyjne, by proces zjednoczenia mógł się zakończyć, pomimo przewidywanych i faktycznie obecnych później utrudnień i wstrząsów. Ze względu na różnorodność państw, które mają być częścią regionalnego europejskiego projektu, oraz ich historyczną przeszłość, Federacja Europy Środkowej nie mogła być porównywana do żadnego innego wielkiego do tej pory projektu. Jako nowy typ, nie powinna też według niego pożyczać swoich instytucji od Ameryki Północnej lub Federacji Szwajcarskiej. Musiała je wypracować i dostosować, dzięki wyobraźni i twórczemu wysiłkowi oraz doświadczeniu historycznemu, do swojego szczególnego położenia i potrzeb. Planowana wspólnota winna posiadać kompetencje decyzyjne i wykonawcze niezależne od krajów związkowych, w tym organy ustawodawcze, wykonawcze i sądownicze, a jej kierownictwo uprawnienia do sprawowania bezpośredniej władzy nad obywatelem. W jego ocenie nie ma odwrotu po wojnie od funkcjonalnego jednoczenia się Starego Kontynentu, przy czym w przypadku Europy Środkowej koncepcja jej poważniejszej integracji pozostanie abstrakcyjna do czasu, aż jej mieszkańcy będą myśleć w kategoriach czysto narodowych ${ }^{44}$.

Niezwykle interesująco brzmią również na tle analizowanego projektu Konstytucji Federacji Środkowo-Europejskiej zapisy przyszłej ustawy zasadniczej przygotowane przez „białych” Rosjan. Z uwagi na tematykę artykułu warto przywołać i porównać te wizje kontynentalnego bezpieczeństwa, które odnosiły się do Polski i rozważanej z jej udziałem wspólnoty. Już pierwsze zawarte w niej sformułowania

\footnotetext{
${ }^{43}$ A. Muhltstein, The United States, s. 36.

44 Tamże, s. 36-41; F. Gross, Federacje, s. 42.
} 
dotyczące powiązania Ukrainy ze stolicą w Kijowie i Białorusi w Mińsku (autonomicznych organizmów państwowych, aczkolwiek z prawem wyjścia), ze składem państwa rosyjskiego, dawały pogląd o wizji sąsiedzkich stosunków, a kolejne zapisy dotyczące religii prawosławnej oraz przywracania kojarzonych z zaborami symboli państwowych, jednoznacznie wskazywały na wolę kontynuowania przez te antykomunistyczne środowiska tradycji mocarstwowych i panslawistycznych. Nie rozpraszały obaw, a wręcz je mogły w powiązaniu z wcześniejszymi uwagami tylko potęgować stwierdzenia, że Polacy wraz z Finami są „uważani za narody niezależne, którym zapewnia się niezależność, bliską współpracę polityczną i gospodarczą oraz przyjacielskie stosunki" 45 . Te paternalistyczne określenia pojawiły się obok zapisów o zapewnieniu przez Rosję bezpieczeństwa własnych granic, także w basenie Bałtyku, poprzez powzięcie „wszelkich możliwych środków do rozwiązania tego życiowego problemu w drodze pokojowych umów i wzajemnej zgody z narodami Pribałtyki" ${ }^{\prime 6}$. Te demotywujące do szerszych rozmów sformułowania, którym towarzyszyły zapisy o Rosji jako krzewicielce pokoju i sprawiedliwości, a także arbitrze wykluczającym wzniecanie wszechświatowych konfliktów oraz zwolenniczce politycznego, ekonomicznego i kulturalnego rozwoju narodów, determinowały na przyszłość zachowania każdego rodzaju wspólnoty Europy Środkowo-Wschodniej (nie wspominając o poszczególnych krajach spoza niej lub bez jej utworzenia), która musiała się liczyć z potencjalnymi problemami nawet po upadku systemu komunistycznego. Gwoli ścisłości, również z perspektywy zachodniej należało brać pod uwagę inne niepożądane dla regionu zjawiska, a szczególnie ryzyko pozostania „Europą B” wobec mniej dotkniętej wojną, a i wcześniej zasobniejszej „Europy A”.

\section{PARADYGMAT REALISTYCZNY \\ A PRZYCZYNY NIEPOWODZENIA PROJEKTU}

Próbując rozważać przyczyny niepowodzeń polskich projektów integracyjnych, w tym ewentualnego utworzenia będącej częścią światowego systemu bezpieczeństwa Federacji Środkowo-Europejskiej, należy na początku przywołać czynniki determinujące jego istotę, a następnie odnieść się do zachodzących dynamicznie procesów w stosunkach międzynarodowych, bazując na przyjętych pojęciach odnoszących się do realizmu politycznego. W nowożytnej myśli politycznej wyróżniono kilka koncepcji jego kształtowania się, ale każda $\mathrm{z}$ nich była związana

\footnotetext{
${ }^{45}$ ABUJ, sygn. 11852, Konstytucja państwa rosyjskiego - projekt z 1946 r., k. 65.

46 Tamże.
} 
ze stanem, w którym funkcjonują zabezpieczenia instytucjonalne, prawne, polityczne, ekonomiczne i militarne przed przemocą, pozwalające zachować status quo w zakresie terytoriów, jak również towarzyszący im poziom adekwatnego do pozycji państw prestiżu. Każdy system bezpieczeństwa posiada ponadto względnie trwały układ relacji pomiędzy jego uczestnikami, a dzięki jego strukturze można określić pozycje wróg-przyjaciel, zdefiniować jego kreatorów i moderatorów, tym samym odróżnić „zwykłych” odbiorców sygnałów i decyzji od nadawców, a także poruszać się na podstawie przyjętych zasad ${ }^{47}$. Jednak przydatność metod normatywnych w prognostyce międzynarodowej jest poważnie ograniczona, gdy mamy do czynienia z ogromną dynamiką wydarzeń i towarzyszącą im złożonością zachodzących procesów. Uniemożliwia to praktycznie ekstrapolację warunkową, ograniczając prawdopodobieństwo prognoz do jednego podmiotu lub bardzo poważnych uogólnień ${ }^{48}$. II wojna światowa rozchwiała, a następnie obnażyła słabość wersalskiego systemu bezpieczeństwa międzynarodowego, wpychając świat w pozbawiony zasad moralnych stan przeciwstawnych interesów i konfliktów, umożliwiających naturze ludzkiej przetestowanie się w nowej sytuacji. Towarzyszyła temu dyskusja na temat dwóch szkół fundamentalnie różniących się w poglądach na naturę człowieka, społeczeństwo i politykę. Pierwsza z nich przyjęła tezę o jego wrodzonej dobroci, a obserwowany „nieład” miałby być wynikiem niedostatku wiedzy i niezrozumienia, bądź demoralizacji odizolowanych jednostek lub grup. Wierzyć ona zatem nakazuje, że w wyniku edukacji oraz sporadycznego użycia siły, można racjonalny, moralny, wywiedziony z uniwersalnych prawomocnych i abstrakcyjnych zasad świat, przywrócić. Druga szkoła natomiast uważa, że jego niedoskonałość jest wynikiem sił tkwiących w naturze człowieka, a chcąc ulepszać ten pierwszy, należy działać zgodnie z nim, a nie przeciwko. Jako że jest on ze swej istoty pełen przeciwstawnych interesów i zrodzonych zeń konfliktów, to pełna realizacja w stosunkach międzynarodowych zasad moralnych jest niemożliwa lub utrudniona $\mathrm{z}$ uwagi na konieczność równoważenia wielu różnych interesów w celu rozwiązywania konfliktów. Szkoła ta, jak pisał Morgenthau, postrzega „system mechanizmów gwarantujących zachowanie równowagi politycznej (checks nad balances) jako uniwersalną zasadę dla wszystkich pluralistycznych społeczności. [...] Jej celem jest raczej mniejsze zło niż najwyższe dobro"49.

Prezentowane już u podstaw światowego konfliktu zachowania polityczne przypominały hobbesowski stan natury i „trwającą wojnę wszystkich przeciwko

${ }^{47}$ W. Paruch, K. Trembicka, Typologia systemów bezpieczeństwa w XIX i XX wieku, Lublin 1996, s. 13-14.

${ }^{48}$ J. Kukulka, Teoria, s. 262.

${ }^{49}$ H.J. Morgenthau, Polityka między narodami. Walka o potęge i pokój, Warszawa 2010, s. 19. 
wszystkim”, legitymizując tym samym drugą szkołę reprezentującą filozofię realizmu politycznego. Jej kilka podstawowych zasad pozwala zrozumieć ówczesną politykę międzynarodową w jej rzeczywistym kształcie. Aby móc tego dokonać, musimy uznać, że jej źródłem jest niezmieniona od wieków natura ludzka, która podlega rozumowemu badaniu, a szczególnie jej pragnienie władzy ${ }^{50}$. Tym samym, zamierzając ulepszać społeczeństwo, należy zaakceptować rządzące nim prawa, których negowanie, skoro są niezależne od naszej woli, groziłoby nieodmiennie porażką. Realizm wyłaniający się z filozofii Tukidydesa, Machiavellego, Hobbesa, Rousseau, a później poddany testowaniu w połowie XX wieku przez Reinholda Niebuhra, Edwarda Halleta Carra, Johna Hertza, Georga Kennana, Waltera Lipmanna, Hansa Morgenthkau czy też Raymonda Arona, charakteryzuje sceptycyzm wobec projektów pokojowych i przekonanie, że potęga i siła militarna są zasadniczymi zmiennymi decydującymi o stanie, ukierunkowanych na dysponujących nimi państw, stosunków międzynarodowych ${ }^{51}$. Tym samym to suwerenne państwa i ich liderzy działają w warunkach braku hierarchii i władzy zwierzchniej, stawiając wszystkich pozostałych w sytuacji potencjalnego zagrożenia. Czasowy charakter sojuszy sprawia, że każdy może być potencjalnym wrogiem i przyjacielem, czy też pozbawionym kwalifikacji moralnych partnerem poszukującym czynników rozstrzygających jego dylemat bezpieczeństwa.

Zdaniem badaczy teorii realizmu, to państwa i ich decydenci są kluczowymi podmiotami dla zrozumienia stosunków międzynarodowych, obserwuje się przy tym wyraźny podział pomiędzy polityką zewnętrzną i wewnętrzną oraz ich zmagania o potęgę i pokój ${ }^{52}$. Dążenie do nich jest pochodną aktywności człowieka i tkwiących w jego naturze zachowań (agresywnych lub samozachowawczych instynktów, nawyków, żądzy, głupoty), państwa lub też wynika z charakteru całego systemu. Podejmując ten kontekst możemy z przewidywanych na przykład działań drugowojennych przywódców wnioskować, jakie były ich cele w określonych okolicznościach sprawowania władzy. Sprawdzanie racjonalnych hipotez za pomocą faktów wiąże wtedy przywoływaną wcześniej teorię z ówczesną polityką międzynarodową. Drogowskazem w gąszczu faktów i wydarzeń winno być zdefiniowanie pojęcia interesu rozumianego w kategoriach potęgi, co pozwala odczytać motywy działań i udzielić wskazówek co do kierunku kolejnych decyzji. Oczywiście nie zawsze ich polityka podlega racjonalnym przewidywaniom, bowiem elementy osobowościowe, uprzedzenie lub subiektywne preferencje bądź inne słabości, mogą ją przekierować

${ }^{50}$ P. ŚPIEWAK, Realiści i świat. Realizm polityczny wedlug Hansa Morgenthaua, „Przegląd Polityczny" 2010, nr 103/104, s. 16.

${ }^{51}$ A. Wojciuk, Dylemat potęgi. Praktyczna teoria stosunków międzynarodowych, Warszawa 2010, s. 24-25; T. Łoś-NowaK, Stosunki międzynarodowe, s. 43-48.

52 Tamże. 
na inne tory, czego byliśmy świadkami w okresie II wojny światowej. Oznacza to również, że zakładana w niej suwerenna równość państw może być złudna i te dzierżące oręż potęgi militarnej są $\mathrm{w}$ stanie ją obnażyć, ustanawiając kontrolę nad innymi w przypadku zaistnienia ku temu warunków, a zwłaszcza ujawnienia się weryfikowalnej empirycznie słabości. Realizm polityczny potwierdza tym samym, że uniwersalne zasady moralne nie mogą się odnosić do przefiltrowanych napotkanymi w odpowiednim czasie okolicznościami działań państw. One nie mogą sobie pozwolić, by wynikająca z nich dezaprobata dla naruszania wolności stanęła na drodze do sukcesu. Także w tym kontekście nie jest możliwe połączenie aspiracji jakiegoś narodu z uniwersalnymi prawami rządzącymi światem, gdzie wszyscy dysponujący odpowiednią potęgą są wystawieni na pokusę realizacji partykularnych interesów ${ }^{53}$. Uzupełnia ten obraz zasada kija i marchewki, która pozwala „zaproponować” państwom o mniejszym potencjale, drogą perswazji lub poprzez presję pośrednią, opiekę silniejszych. Gdy ją dobrowolnie przyjmą, to warunki wasalizacji będą mniej dolegliwe (oddziaływanie soft power), niż w przypadku jej odrzucenia (reaktywność hard power). Jak widać zatem, już sama możliwość skutecznego użycia siły stanowi o jej wyższości nad prawem i moralnością, stąd nie dziwi przepaść dzieląca je także od zasad realizmu politycznego. Doskonale obrazuje ten rozdźwięk w praktyce związek pomiędzy atakiem III Rzeszy i ZSRR na Polskę w 1939 roku a zajętym stanowiskiem naszych zachodnich sojuszników. Podobnie należy oceniać ich postawę w kategoriach późniejszej uległości wobec Moskwy, co do akceptacji dla jej panowania w Europie Środkowo-Wschodniej.

Wspomniano już wcześniej, że przygotowany w Stanach Zjednoczonych Projekt Konstytucji Stanów Zjednoczonych Europy nie spotkał się z większym zainteresowaniem, poza samymi paneuropeistami, z uwagi na realizowaną przez prezydenta Roosevelta politykę prowadzenia wojny i przyszłych rozwiązań geostrategicznych podporządkowanych interesom w Azji i na Pacyfiku. Cenił on sobie wyżej stosunki z ZSRR w wojnie z Japonią oraz dwoma potencjalnymi światowymi „policjantami” - Wielką Brytanią i Chinami, niż idealistyczne dla niego formy integracji Starego Kontynentu, pomimo że jeszcze na przełomie 1942/43 roku sygnalizował Polakom zadowolenie z ich starań na rzecz budowy regionalnego systemu bezpieczeństwa opartego o konfederację państw kierujących się wolą zaprowadzenia demokratycznego porządku w tej części świata ${ }^{54}$. Symptomatycznie wypowiedział się w tej sprawie nieco później, w sierpniu 1943 roku, w kontekście zmiany strategii wobec Europy, krytykujący ten krok, a przesunięty do innych prac w administracji amerykańskiej, były pracownik Departamentu Stanu doradzający

\footnotetext{
${ }^{53}$ H.J. Morgenthau, Polityka, s. 19.

${ }^{54}$ K. Łastawski, Od idei, s. 100; A. Barabasz, Polacy, s. 142-143.
} 
Rooseveltowi w sprawach sowieckich i znający metodologię działań Moskwy w stosunkach międzynarodowych William Bullitt: „Europa podzielona na radziecką strefę wpływu, która będzie komunistyczna, i brytyjsko-kapitalistyczną, wytworzy w najlepszym wypadku niespokojny rozejm, lecz nie pokój. Europa będzie innym domem podzielonym wbrew sobie" ${ }^{55}$. W kwestiach Polski wyraźnie różnił się zatem z amerykańskim prezydentem, który uważał, że jej elity mają przesadne wyobrażenie o tym, co mogą postanowić politycy, ignorując zupełnie geograficzne realia, co odzwierciedlają jego słowa do jej ambasadora w grudniu 1943 roku: „Czy oczekujecie, że my i Wielka Brytania wypowiemy wojnę Joe Stalinowi, jeśli oni przekroczą waszą dawną granicę? Nawet gdybyśmy chcieli, Rosja może wystawić armię dwukrotnie większą niż nasze połączone siły, i my dokładnie nie mamy nic $\mathrm{w}$ tej sprawie do powiedzenia" ${ }^{26}$.

Jeszcze większy polityczny zawód sprawił zwolennikom zjednoczonej Europy Winston Churchill, ulegając strategicznym celom i interesom Stanów Zjednoczonych oraz ZSRR. W zamian utrzymał rolę aktywnego uczestnika w podziale sfer wpływów w Europie, a później członka stałego z prawem veta kształtującej formalnie system światowego bezpieczeństwa Rady w Organizacji Narodów Zjednoczonych. Od początku krytycznie, aczkolwiek do przełomowych momentów wojny maskując swoje stanowisko, wypowiadał się o integracji regionu Związek Radziecki. Początkowo Moskwa opowiadała się za pozostawieniem wyboru przyszłości pozostającym pod okupacją niemiecką narodom, a po 1943 roku i wymuszeniu na Benešu odrzucenia projektu polsko-czechosłowackiej federacji, rozważała wyłącznie koncepcje utworzenia w regionie, faktycznie w przyznanej w Jałcie strefie wpływów związanych z nią ideologicznymi więzami republik ludowych ${ }^{57}$. Jedynym wyłomem sprawiającym problem w jej polityce było utworzenie, mającej swój inspiratorski początek na emigracji, federacji jugosłowiańskiej złożonej z sześciu republik związkowych. Na wychodźstwie został również zapoczątkowany proces integracji państw Beneluksu, który znacząco ułatwił po wojnie proces funkcjonalnego jednoczenia zachodniej Europy ${ }^{58}$.

Odstępstwo Roosevelta oraz Churchilla od Karty Atlantyckiej i od prawa międzynarodowego, pod których hasłami Sprzymierzeni prowadzili wojnę z Niemcami i Japonią, doprowadziło do fiaska wszystkich projektów lansowanych przez środowiska wychodźcze Europy Środkowo-Wschodniej. Krótkowzroczność zwycięzców,

${ }^{55}$ Cyt. za: L.C. Gardner, Strefy wptywów. Wielkie mocarstwa i podziat Europy. Od Monachium do Jatty, Warszawa 1999, s. 191.

56 Tamże, s. 239.

57 Tamże, s. 101; J. Łaptos, Europa, s. 47-67; F. Gross, Federacje, s. 53-56.

${ }^{58}$ Mowa o obejmującej także Luksemburg, belgijsko-holenderskiej unii monetarnej, zob. J. ŁAPTOS, Europa, s. 68; P. WANDYCZ, L. FrendL, Zjednoczona Europa, s. 199. 
podobna do tej, jaką wykazali w 1919 roku, uniemożliwiła wygenerowanie stabilnego ładu międzynarodowego po 1945 roku. Stany Zjednoczone, które dysponowały największym ówcześnie potencjałem gospodarczym, a przy tym wraz z Wielką Brytanią panując na morzach świata, potrzebowały innych niż państwa środkowej Europy partnerów, aby zwycięsko zakończyć wojnę z państwami Osi ${ }^{59}$. Kolejne sukcesy militarne utwierdziły je w przekonaniu, że są predestynowane do tego, aby zaprowadzić na swoich warunkach funkcjonujący do dziś ład międzynarodowy. Wyłaniający się nowy porządek świata ujawnił także aspiracje zainteresowanych walką faktycznie o międzynarodowy prestiż państw. Wielkie mocarstwa już wtedy próbowały na swój sposób zaimponować sobie wzajemnie potęgą militarną, osiągnięciami technologicznymi, potencjałem gospodarczym oraz zasadami politycznymi osłabiającymi morale potencjalnych przyjaciół i przeciwników. W pierwszym przypadku chodziło o utrzymanie sojuszniczej lojalności, natomiast $\mathrm{w}$ drugim o odstraszenie i sprawdzenie, czy nie są pozornymi potęgami. Doskonale oddają to słowa przywoływanego już wcześniej Hansa Morgenthaua, który pisał: „w polityce międzynarodowej błędem jest angażowanie się w politykę blefu, jednakże nie mniejszym jest popadnięcie $\mathrm{w}$ inną skrajność i zadowolenie się reputacją potęgi nie odzwierciedlającej siły. Doskonałym przykładem «negatywnej polityki prestiżu» było postępowanie Stanów Zjednoczonych oraz Związku Radzieckiego w okresie przedwojennym i w pierwszych latach wojny" ${ }^{60}$. Uzupełnijmy narracje stwierdzeniem, że te pierwsze miały już wcześniej zadatki na najpotężniejsze państwo świata i sugestywnie deklarowały sprzeciw wobec niemieckiego i japońskiego imperializmu, czego te dwa kraje najwyraźniej nie chciały dostrzec lub nie dostrzegły wypowiadając mu wojnę. Zatem można postawić w tym miejscu tezę, że do starcia przyczynił się brak polityki prestiżu opartej na niezachwianej reputacji siły militarnej. Jej zdeprecjonowanie przez państwa „Osi” skutkowało dopiero po czasie, nie tylko odwetem, ale również zmianą pozycji Waszyngtonu w stosunkach międzynarodowych. Podobna sytuacja miała miejsce początkowo ze Związkiem Radzieckim, którego prestiż militarny, pomimo chwilowego sukcesu po najeździe na Polskę, został obalony podczas wojny fińskiej, a później ponownie podczas wschodniego Blitzkriegu Hitlera, by znów się odbudować. W sferze przypuszczeń pozostaje, jak potoczyłyby się losy świata, gdyby nie popełniono tych błędów w ocenach, choć niewykluczone, że i tak ludzkie skłonności powrotu do stanu natury i przenoszenia z niego zachowań wzięłyby górę nad rozumem.

${ }^{59}$ Por. T. KoŚMider, J. ŚLIPIEC, J. ZuZIAK, Europejska integracja militarna. Sojusze wojskowe XX wieku, Warszawa 2011, s. 116.

${ }^{60}$ H.J. Morgenthau, Polityka, s. 110. 
Czego zatem zabrakło polskim politykom budującym koncepcje regionalnego bezpieczeństwa opartego o przywoływaną Federację Środkowo-Europejską? Wydaje się, że zbyt idealistycznie podeszli do metod rozwiązywania ówczesnych konfliktów, nie dostrzegając, że pojęcie prawa i sprawiedliwości oraz moralność $\mathrm{w}$ stosunkach międzynarodowych niewiele znaczą w starciu z realizmem politycznym, którego paradygmat święcił swój wielki triumf. Polacy zapomnieli lub chcieli nie pamiętać o Machiavellim, Spinozie czy też Weberze i ich maksymach, które utrzymywały, że w świecie kryzysu i anarchii u polityków dominują wyłącznie względy skuteczności, a nie inne zasady ${ }^{61}$. Już 1939 rok powinien im uzmysłowić, że moralne potępienie przez papieża najazdu i tym samym wzmocnienie wyrosłego na tomizmie przekonania o prowadzeniu wojny sprawiedliwej, w żadnym stopniu nie przekładało się na standardy moralności międzynarodowej i realizację zobowiązań sojuszniczych. Naszym elitom, przy tak dużej dynamice wydarzeń, mogło również zabraknąć umiejętności analizowania lub świadomego odrzucania występujących podobieństw, także w przypadku sytuacji nierealnych i nieznanych, aczkolwiek możliwych i prawdopodobnych. Być może wsparto się w większym zakresie pasywnymi metodami prognostycznymi zamiast aktywnymi - teleologicznymi, które są ukierunkowane na praktyczny wybór i decyzje w stosunkach międzynarodowych ${ }^{62}$. A może było tak jak pisał Cat-Mackiewicz, że „Polacy nie umieją sobie dać rady z pojęciem - siła polityczna" i oceniają jej część biorąc za całość ${ }^{63} \mathrm{Z}$ pewnością $\mathrm{w}$ przypadku polistrategii, jeżeli faktycznie mieliśmy $\mathrm{z}$ nią do czynienia, brakło szerszej analizy aktywności Francji i Wielkiej Brytanii wobec Niemiec z końca lat 30. XX wieku, a także analogicznych badań nad polityką Stanów Zjednoczonych, które wykazywały okazjonalnie zainteresowanie Europą, kosztem strefy Azji i Pacyfiku. Amerykanie, czego nie dostrzegli polscy politycy, po zwycięstwie Armii Czerwonej pod Stalingradem i pod wpływem prowadzonej przez Stalina polityki zagranicznej, od 1943 roku absolutyzowali trwałość jego dominacji w Europie, co wraz z postępami na froncie nabrało znamion dogmatu. Uznali zatem, że rządzone przez niego państwo ma prawo w obawie o własne bezpieczeństwo do konsekwentnego przeciwstawiania się planom zjednoczenia Europy, bowiem mobilizacja podzielonych sił krajów Starego Kontynentu w „blok zachodni" mogłaby dać im potęgę zdolną zagrozić jego bezpieczeństwu i uzgodnionej pozycji w stosunkach międzynarodowych, a w efekcie uniemożliwić dostęp

${ }^{61}$ M. Weber, Polityka jako zawód i powolanie, Kraków 1998, s. 96.

${ }^{62}$ Szerzej o metodach i znaczeniu analiz prognostycznych w: J. KuKUŁKA, Teoria, s. 260-262.

${ }^{63}$ Cat-Mackiewicz łączył w tym pojęciu: wielkość państwa i jego geograficzne położenie, bogactwo jego mieszkańców, wydajność przemysłu wojennego, liczba rekruta, właściwe sojusze polityczne, itd., S. CAT-MaCKIEWICZ, Lady Mackbeth umywa ręce, w: Realizm polityczny. Przypadek polski. Wybór tekstów, oprac. J. Kłoczowski, Kraków 2008, s. 233. 
do ekskluzywnej grupy państw „dzielących i rządzących” lub ją ograniczyć (także nie $\mathrm{w}$ ich interesie) i zaburzyć wypracowywaną w sporach o potęgę równowagę sił. Niepowodzenie projektów związanych z budową regionalnego systemu bezpieczeństwa międzynarodowego nie jest jednak wyłączną i najważniejszą pochodną polskich błędów, ale raczej następstwem utwierdzenia się, poza ich możliwościami wpływu, nowego paradygmatu, gdzie zwycięzcy z perspektywy budowania potęgi zgodnie stwierdzali, że „wojna działa”, a na przeszkodzie nie stoją przedstawiane do podpisu małym podmiotom zapisy Karty Atlantyckiej. Przywoływany wyżej Cat-Mackiewicz puentował taką postawę słowami: „Polityka ta nie była szlachetna, ale była narodowo-egoistyczna, realistyczna. Tego ostatniego nie można powiedzieć o polityce polskiej",64.

Niekorzystny i niezawiniony przez państwa Europy Środkowo-Wschodniej przebieg II wojny, brak akceptacji „wielkiej dwójki” na totalny antysowietyzm będący następstwem akceptacji wpływów Rosji w świecie w zamian za ciężar walk z III Rzeszą, w mniejszym stopniu antagonizmy sąsiedzkie wpływające na kształt rozmów i wynikająca z nich nieufność, zbyt szeroki zakres proponowanej integracji, w jakimś stopniu oddają szersze przyczyny upadku polskiej polityki, a tym samym projektu federacji. Należałoby także z perspektywy społecznej zauważyć, że niekoniecznie po wojnie obywatele potencjalnych państw sygnatariuszy wspólnoty pośpieszyliby w kierunku jej zawiązania tylko dlatego, że tego oczekują politycy, skoro wcześniej nie odwzajemniały sympatii. Ścisłości i rozległości organizacji międzynarodowej powinna towarzyszyć zażyłość stosunków pomiędzy narodami, ich wzajemne zaufanie do siebie, forma autentycznej przyjaźni przeważającej ruchy odśrodkowe i indywidualistyczne, a nie polityczne oświadczenia. Dopóki nie wystąpiłoby takowe uspołecznienie narodów, nie warto byłoby rozważać upaństwowienia zbiorowości, chyba że siłą wzorowaną na poprzednich systemach totalitarnych. Równie ważnym problemem pozostawałaby obecność w strukturach federacji częściowo ponadnarodowej władzy, i to tym bardziej obcej, im większa ją tworzyłaby liczba podmiotów. O ile w utworzonym na bazie proporcjonalnych wyborów parlamencie nie będzie to stanowić poważnego zagrożenia, o tyle takowe może się pojawić w przypadku zastosowania tej samej zasady przy tworzeniu rządu, bowiem w tym przypadku będzie się trzeba uciekać do środków mniej lub bardziej mechanicznych, jak na przykład kolejność sprawowania funkcji, co oznacza ryzyko ograniczenia wpływów poszczególnych państw i odpowiadających temu ich pozycjom, a zwłaszcza ich czasami nagłym potrzebom. Niebezpieczeństwo wzrastałoby wraz z rozmiarem federacji. Jeżeli połączyłyby się dwa lub trzy państwa o podobnych parametrach podmiotowych,

${ }^{64}$ Tamże, s. 229. 
to ten problem mógłby być zdecydowanie mniej widoczny, niż w przypadku tej samej liczby państw, ale o odmiennych potencjałach. O ile Polska sfederowałaby się po wojnie z Czechosłowacją, o tyle nie byłoby obaw o dostateczną reprezentację w związkowym parlamencie i rządzie. Ale już po dołączeniu Węgier i państw bałtyckich oczekiwane przez nas proporcje mogłyby być praktycznie nieakceptowalne. Politycy emigracyjni nie chcieli również dostrzegać woli innych narodów i ich przedstawicieli do samostanowienia po ewentualnym odzyskaniu wolności w lansowanych przez nich granicach, nie wspominając o sygnalizowanym sprzeciwie wielkich mocarstw. Nawet stosunkowo najbliższy im Beneš współpracując z Sikorskim przy koncepcji federacji uważał, że łączenie się małych państw w większe związki nie będzie możliwe bez ich poparcia, i w odróżnieniu od polskiego premiera twierdził, że miałyby one uzasadnienie, gdyby stanowiły „logiczny krok w kierunku konsolidacji całej Europy, będącej elementem czegoś w rodzaju światowego Commonwealthu" ${ }^{\prime 65}$. Spowodowana Monachium trauma i wynikające $z$ niej ograniczone zaufanie do Zachodu, miało skutkować jego staraniami o udział ZSRR w organizacji bezpieczeństwa Europy i zachowanie w niej równowagi sił, w czym wyraźnie różnił się od partnerów, którzy uważali, że nie należy demonstrować słabości, lecz stanąć na drodze sowieckiej ekspansji poprzez demonstrację siły w postaci proponowanego bloku państw ${ }^{66}$. Rzeczpospolita musiałaby się również uporać $\mathrm{w}$ ramach proponowanej wspólnoty z problemem skłócenia węgiersko-czechosłowackiego, w przypadku jej kolejnego rozszerzenia, z zindywidualizowanymi, w tym sprzecznymi interesami na przykład Rumunów i Bułgarów niechętnych antyniemieckim i antysowieckim postawom. Jednocześnie wszyscy poza Polakami podkreślali, że objęcie federacją regionalną państw o tak różnych interesach jak Estonia na północy, Austria na zachodzie, Grecja na południu i ewentualnie Ukraina na wschodzie, to kolejny dowód na brak realizmu politycznego naszych elit.

Także z perspektywy regionalnego bezpieczeństwa należało się liczyć $\mathrm{z}$ odwrotnym od zamierzonego skutkiem, a zatem możliwym spadkiem poczucia wspólnotowości. Mogły bowiem powstać konkurencyjne federacje pragnące zrównoważyć potencjał tej pierwszej, uciekające się do innych niż pokojowe metod rozwiązywania zawsze obecnych w stosunkach międzynarodowych konfliktów. Z polskiej perspektywy zatem optymistyczne przypuszczenia o możliwości budowy regionalnego organizmu i przewodzeniu nim należałoby skonfrontować z faktycznymi odczuciami sąsiadów wobec nas, a w przypadku niekorzystnych ocen - mieć nadzieję na ich zmianę w przyszłości.

\footnotetext{
${ }^{65}$ J. ŁaPtos, Europa, s. 35.

${ }^{66}$ Tamże.
} 
Pojawiły się także w tych dyskusjach głosy wskazujące na szkodzącą merytorycznej dyskusji o kształcie powojennej Europy nadmierną emocjonalność u wielu polityków, tak jakby „idea federalistyczna była słońcem wschodzącym za chmurami obecnej wojny", a wobec których należy wymagać ówcześnie i po zwycięskiej wojnie chłodnej kalkulacji, by „leczyć rany najbardziej wypróbowanymi środkami, a nie rzucać się na ryzykowne eksperymenty" ${ }^{\prime 67}$.

\section{PODSUMOWANIE}

Projekt Konstytucji Federacji Środkowo-Europejskiej należał do jednego z nielicznych, które tak dalece formowały podstawy ustrojowo-instytucjonalne wspólnotowego podmiotu. Już sama jego konstrukcja prawna wzbudzała zainteresowanie co do możliwości jej faktycznego wdrożenia. Potencjalne państwa członkowskie były wszak sobie w założeniu geopolitycznie bliskie, gospodarczo często wzajemnie uzupełniające się, historycznie w przeszłości powiązane, komunikacyjnie współzależne, zdatne militarnie do wykonywania wspólnych zadań. Pozbawiony wielu cech realizmu projekt był następstwem po części emocjonalnego rozwiązania spraw polskich w duchu kontrolowanego przekazania części własnej suwerenności podmiotowi, który w dużym stopniu miał pozostawać pod rodzimą kontrolą, a jednocześnie stanowił alternatywę dla pojawiającego się ryzyka ograniczenia lub braku podmiotowości kraju. Mocarstwa zachodnie, akceptując na dekady sowiecką dominację w Europie Środkowo-Wschodniej, nie zrozumiały ani politycznego, ani gospodarczego znaczenia regionu dla równowagi i bezpieczeństwa Starego Kontynentu, odmawiając wsparcia emigracyjnym projektom. Czas szybko pokazał skalę ich zaniedbań. $Z$ uwagi na fundamentalne różnice doktrynalne i antynomie interesów wojenny sojusz Stanów Zjednoczonych oraz Związku Radzieckiego szybko ewoluował po 1945 roku w kierunku bipolarnym, stawiając realnie poza wpływem na globalne bezpieczeństwo inne państwa. Okres względnej prosperity w stosunkach Wschód-Zachód przerwało przemówienie byłego brytyjskiego premiera Winstona Churchilla z 1946 roku, mówiącego o „zapadającej w poprzek kontynentu żelaznej kurtynie", które symbolicznie zapoczątkowało kres ustępstw wobec agresywnych zachowań Moskwy ${ }^{68}$. Potwierdziły zmianę strategii późniejsze słowa prezydenta Trumana do amerykańskiego Kongresu.

Od drugiej połowy lat 40. XX wieku mieliśmy już do czynienia z budową podzielonego ideowo dwubiegunowego świata, którego częścią była dostrzegana

${ }^{67}$ M. Szerer, Federacje a przyszlość Polski, Londyn 1942, s. 28.
${ }^{68}$ W. Churchill, Krew, znój, tzy i pot, Poznań 1989, s. 228, 230. 
w wypowiedziach i działaniach polityków obu stron wojenna retoryka. W tamtym okresie ponownie z pewną nadzieją na zmianę niekorzystnych dla Europy Środkowo-Wschodniej rozstrzygnięć przystąpili do kolejnych prac koncepcyjnych pozostali na emigracji przedstawiciele zamieszkujących ją ujarzmianych przez komunizm narodów, liczący na wybuch nowego konfliktu i zwycięstwo demokracji zachodniej, a w ślad za tym - na przywrócenie im wolności, lub wycofanie się ZSRR z regionu pod wpływem techniczno-gospodarczego nacisku Zachodu. Pomóc w tych planach miało również wsparcie kolejnego garnituru merytorycznie lepiej przygotowanych do starcia $z$ totalitaryzmami brytyjskich, francuskich i amerykańskich elit. Jednak niekoniecznie ich poglądy były w pełni zbieżne z oczekiwaniami wychodźstwa, bowiem ich pierwsza generacja, według Habermasa, kierowała się dwoma bezpośrednimi celami, z których pierwszy dotyczył kategorycznego zakończenia krwawej historii konfliktów między europejskimi narodami, natomiast drugi objęcia procesem integracji postfaszystowskie Niemcy, które po odrodzeniu się z wojennych zniszczeń znowu mogłyby zagrozić stabilności kontynentu ${ }^{69}$. Ich uwaga skupiała się również na eliminacji we własnych krajach wspieranej przez Moskwę ideologii komunistycznej oraz na przynoszącej pierwsze efekty odbudowie funkcjonalnej kontynentu, dla której wsparciem były powstające organizacje i ruchy promujące jedność europejską ${ }^{70}$.

Podążanie w kierunku kontynentalnej federacji lub konfederacji wykluczyło z rozważań i dialogu o przyszłości Europy zamieszkujące jej środkowo-wschodnią część społeczeństwa, a tym samym ich emigracyjnych przedstawicieli ${ }^{71}$. Czy zatem ich historyczne propozycje tracą bezpowrotnie na współczesnym politycznym znaczeniu? Z pewnością tak nie jest, jeżeli na podobnych przesłankach ukształtowały się dekady później polskie warunki polskiej obecności w strukturach Unii Europejskiej i Sojuszu Północnoatlantyckim, a które ogniskowały się wokół wspólnego od setek lat problemu zagwarantowania Rzeczpospolitej minimalnych warunków

69 J. Habermas, Dlaczego Europa potrzebuje Konstytucji, „Studia Philosophica Wratislaviensia” 2 (2007), fasc. 1, s. 168.

${ }^{70} \mathrm{Na}$ przykład w Paryżu powstaje w grudniu 1946 roku Europejska Unia Federalistów, a miesiąc później w Londynie Ruch Jedności Europejskiej pod przewodnictwem Winstona Churchilla, Wspólnota europejska w oczach Polaków. Wybór publicystyki i dokumenty, oprac. Z. Najder, Londyn 1989, s. 16-17.

${ }^{71}$ Zagadnieniami środkowoeuropejskiego federalizmu zajmowały się również na emigracji wyspecjalizowane ośrodki badawcze, w tym grupujący naukowe autorytety i wydające pismo „Sprawy Międzynarodowe" - Polski Instytut Badania Spraw Międzynarodowych z siedzibą w Londynie. Do jesieni 1948 roku przygotowano ponad 40 ekspertyz zawierających analizy dotyczące idei zjednoczenia Europy Środkowo-Wschodniej, M.S. WolAŃSKI, Europa, s. 84-110; TEGOż, Federalizm w myśli politycznej polskich ugrupowań emigracyjnych po II wojnie światowej, w: Federalizm. Teorie i koncepcje, red. W. Bokajło, Wrocław 1998, s. 302-307. 
jej suwerenności i bezpieczeństwa. Świadomość naszych elit pozostaje w tym względzie niezmienna od lat, różni je natomiast moment, w jakim wyrażały swoje stanowisko w odniesieniu do posiadania lub nie niepodległości. W przypadku jej braku lub występujących ograniczeń w podmiotowości, towarzyszyło inspiratorom projektów integracyjnych, i to nie tylko tym wcześniej wymienionym, przekonanie o konieczności scedowania wybranych praw na struktury ponadnarodowe w celu posiłkowania się ich aktywnością przy jej odzyskiwaniu. Pomimo problemów z oceną lub właściwym wykorzystaniem następujących po sobie wydarzeń i nadmiernej ufności w sprawiedliwość, prawo i moralność międzynarodową, należy pozytywnie ocenić emigracyjne próby zagwarantowania Polsce bezpiecznego miejsca w powojennej Europie. Ich głównym bowiem celem miało być zarekomendowanie wolnemu po wojnie narodowi najlepszych dla jego przyszłości rozwiązań łączących go aksjonormatywnie z cywilizacją łacińską. Z tej perspektywy projekt Konstytucji Federacji Środkowo-Europejskiej wykracza swoimi zapisami poza wyłączną wartość poznawczą i może stać się przedmiotem politycznych i prawnych analiz w przyszłości.

\section{BIBLIOGRAFIA}

\section{Źródła}

Archiwum Biblioteki Uniwersytetu Jagiellońskiego w Krakowie [ABUJ]:

sygn. 11839, sygn. 11840, sygn. 11852

O jedność Europy. Antologia polskiej XX-wiecznej myśli europejskiej, oprac. S. Łukasiewicz, Warszawa: Urząd Komitetu Integracji Europejskiej 2007.

Wspólnota europejska w oczach Polaków. Wybór publicystyki i dokumenty, oprac. Z. Najder, Londyn: Polonia 1989.

Realizm polityczny. Przypadek polski. Wybór tekstów, oprac. J. Kłoczowski, Kraków: Ośrodek Myśli Politycznej 2008.

\section{Literatura}

Akcja niepodległościowa na terenie międzynarodowym 1945-1990, red. T. Piesakowski, Londyn: Polskie Towarzystwo Naukowe ma Obczyźnie 1999.

BARABASZ A., Polacy i Polska wobec idei integracji europejskiej w latach 1915-1957, Toruń: Adam Marszałek 2008.

Borzym A., Sadowski J., Polscy Ojcowie Europy, Warszawa: Trio 2007.

BRZEZIŃSKI A.M., Kwestia powojennej organizacji bezpieczeństwa w polityce zagranicznej

Rządu RP na Uchodźstwie 1939-1945, Łódź: Wydawnictwo UŁ 1999.

Churchill W., Krew, znój, łzy i pot, Poznań: Zysk i S-ka 1989. 
Europa Środkowo-Wschodnia w polskiej myśli politycznej, red. M. Dymarski i J. Juchnowski, Wrocław: Wydawnictwo UWr 2004.

Federalizm. Teorie i koncepcje, red. W. Bokajło, Wrocław: Wydawnictwo UWr 1998.

GARDNER C., Strefy wpływów. Wielkie mocarstwa i podział Europy. Od Monachium do Jałty, Warszawa: Książka i Wiedza 1999.

Gross F., Crossroads of Two Continents. A Democratic Federation of East-central Europe, New York: Columbia University Press 1945.

Gross F., Federacje i konfederacje europejskie. Rodowód i wizje, Warszawa: Instytut Studiów Politycznych PAN 1994.

GrYgajtis K., Polskie idee federacyjne i ich realizacja w XIX i XX wieku, Częstochowa: Wydawnictwo WSP 2001.

HuXLEY J., Democracy Marches, London: Chatto and Windus 1941.

KISIELEWSKI T., Federacja Środkowo-Europejska. Pertraktacje polsko-czechosłowackie 1939-1943, Warszawa: LSW 1991.

KoŚMIDER T., ŚLIIIEC J., ZuZIAK J., Europejska integracja militarna. Sojusze wojskowe XX wieku, Warszawa: AON 2011.

KukUŁKA J., Teoria stosunków międzynarodowych, Warszawa 2000.

KunCEWICZ J., Zadania i pozycja Polski w układzie powojennym, Paryż-Londyn 1940

ŁAPTOS J., Europa marzycieli. Wizje i projekty integracyjne środkowoeuropejskiej emigracji politycznej 1940-1956, Kraków: Wydawnictwo Naukowe USz 2012.

ŁASTAWSKI K., Od idei do integracji europejskiej, Warszawa: WSP im. J. Korczaka 2003.

Łoś-NowaK T., Stosunki międzynarodowe. Teorie - systemy - uczestnicy, Wrocław: Wydawnictwo UWr 2000.

Morgenthau H.J., Polityka między narodami. Walka o potęgę i pokój, Warszawa: Difin 2010.

Muhltstein A., The United States the Central Europe, New York: New Europe 1942.

O nowy kształt Europy. XX-wieczne koncepcje federalistyczne w Europie Środkowo-Wschodniej i ich implikacje dla dyskusji o przyszłości Europy, red. J. Kłoczowski, S. Łukasiewicz, Lublin: Instytut Europy Środkowo-Wschodniej 2003.

Paruch W., Trembicka K., Typologia systemów bezpieczeństwa w XIX i XX wieku, Lublin: Wydawnictwo UMCS 1996.

PiszczKowski T., Polska a Nowa Europa, Londyn 1942.

Pomian J., Józef Retinger. Życie i pamiętniki pioniera Jedności Europejskiej, Warszawa: Pavo 1994.

Pomian J., Józef Retinger - życie i pamiętniki „szarej eminencji”, Warszawa: Pelikan 1990. RYBARSKI R., Siła i prawo, Warszawa 1936.

SKodLARSKI J., Epilog układu Sikorski-Beneš. Z dziejów polsko-czechosłowackich w latach 1939-1949, Łódź: Wydawnictwo Łódzkie 1988.

SkUza C., Bezpieczeństwo zewnętrzne państwa w programach i działaniach polskich polityków (1939-1955), Szczecin: Wydawnictwo USz 2012.

Szerer M., Federacje a przyszłość Polski, London: P.S. King and Staples 1942.

Wandycz P., Frendl L., Zjednoczona Europa, teoria i praktyka, London: Polonia Book Fund 1965. 
Warszawa nad Tamizą. Z dziejów polskiej emigracji politycznej po drugiej wojnie światowej, red. A. Friszke, Warszawa: Instytut Studiów Politycznych 1994.

WeBer M., Polityka jako zawód i powołanie, Kraków: Znak 1998.

WięCŁAWSKI J., Teoria realizmu Hansa J. Morgenthaua, koncepcje, krytyka i znaczenie dla współczesnych stosunków międzynarodowych, Olsztyn: UWM 2014.

Witkowski G., Józef Retinger, polski inicjator integracji europejskiej, Warszawa: Stowarzyszenie Współpracy Narodów Europy Wschodniej ZBLIŻENIE 2000.

WoJciuk A., Dylemat potęgi. Praktyczna teoria stosunków międzynarodowych, Warszawa: Wydawnictwo UW 2010.

WolaŃSKi M.S., Europa Środkowo-Wschodnia w myśli politycznej emigracji polskiej w latach 1945-1975, Wrocław: Wydawnictwo UWr 1996.

\section{Artykuly}

Cat-Mackiewicz S., Lady Mackbeth umywa ręce, w: Realizm polityczny. Przypadek polski. Wybór tekstów, oprac. J. Kłoczowski, Kraków: Ośrodek Myśli Politycznej 2008.

Habermas J., Dlaczego Europa potrzebuje Konstytucji, „Studia Philosophica Wratislaviensia" 2 (2007), fasc. 1.

KolEndo A.T., O idei federacji polsko-czechosłowackiej - polemicznie, „Dzieje Najnowsze" 1989, nr 2.

Korespondencja w sprawie konfederacji polsko-czechosłowackiej w latach 1940-1943, wyd. S. Stanisławska, „Studia z Najnowszych Dziejów Powszechnych” 4 (1963).

LEWKowicz Ł., Idea polsko-czechosłowackiego związku państwowego w działalności politycznej obozu emigracyjnego (1939-1945). Zarys problematyki, w: Europejskie inspiracje myśli politycznej w Polsce od XIX do XXI wieku. Recepcja - kontynuacja - interpretacja, red. E. Maj, A. Dawidowicz, Ł. Lewkowicz, A. Szwed, Lublin: Wydawnictwo UMCS 2013.

MatusaK P., Polskie koncepcje integracyjne Europy Podziemnej 1939-1945, w: Państwo - ludowcy - myśl polityczna. Księga pamiątkowa ku czci prof. J. Jachymka, red. Z.J. Pietras, A. Wójcik, W. Paruch, Lublin: Wydawnictwo UMCS 1999.

MochlıŃSKI K., Polskie inicjatywy Federacji Europy Środkowo-Wschodniej, w: Akcja niepodległościowa na terenie międzynarodowym 1945-1990, red. T. Piesakowski, Londyn: Polskie Towarzystwo Naukowe na Obczyźnie 1999.

Orzechowska M., Czechosłowacja w polskiej myśli politycznej w okresie II wojny światowej, w: Polska myśl polityczna XIX i XX wieku, t. I: Polska i jej sąsiedzi, Wrocław: Ossolineum 1975.

SIELEZIN J.R., Idea federacji polski-czechosłowackiej jako element gry politycznej w latach 1939-1943, w: Europa Środkowo-Wschodnia w polskiej myśli politycznej, red. M. Dymarski, J. Juchnowski, Wrocław: Wydawnictwo UWr 2004.

ŚPIEWAK P., Realiści i świat. Realizm polityczny według Hansa Morgenthaua, „Przegląd Polityczny" 2010, nr 103/104. 
WANDYCZ P., Próby stworzenia konfederacji polsko-czechosłowackiej podczas drugiej wojny światowej, w: Władze RP na obczyźnie podczas II wojny światowej 1939-1945, red. Z. Bażyński, Londyn: Polskie Towarzystwo Naukowe na Obczyźnie 1993.

WoLAŃSKI M.S., Federalizm w myśli politycznej polskich ugrupowań emigracyjnych po II wojnie światowej, w: Federalizm. Teorie i koncepcje, red. W. Bokajło, Wrocław: Wydawnictwo UWr 1998.

ZAPART R., Władze RP na Uchodźstwie o projekcie polsko-czechosłowackiej współpracy w latach osiemdziesiątych XX wieku, „Studia Polonijne” 35 (2014).

\author{
KONSTYTUCJA FEDERACJI ŚRODKOWO-EUROPEJSKIEJ \\ JAKO WYRAZ INTEGRACYJNEGO IDEALIZMU W BUDOWIE \\ SYSTEMU REGIONALNEGO BEZPIECZEŃSTWA W MYŚLI POLITYCZNEJ \\ POLSKIEGO WYCHODŹSTWA W XX WIEKU
}

Streszczenie

Przedstawiciele ujarzmionych przez totalitaryzmy narodów Europy Środkowo-Wschodniej podjęli podczas II wojny światowej oraz po jej zakończeniu próby lansowania alternatywnych projektów integracji Starego Kontynentu, które miały stać się po uwolnieniu regionu spod sowieckiej dominacji podstawą do dyskusji na temat przyszłości globalnego systemu bezpieczeństwa. W prezentowanym artykule autor przybliża w kontekście polityczno-prawnym jeden z nich, projekt Konstytucji Federacji Środkowo-Europejskiej. a następnie weryfikując na jego bazie hipotezy z teorią polityki międzynarodowej, próbuje odpowiedzieć na pytanie o przyczyny niepowodzenia nie tylko tej propozycji zmian systemowych. Drogowskazem w tych rozważaniach stało się zdefiniowanie, pozwalającego odczytać motywy działania podmiotów, pojęcia interesu narodowego rozumianego w kategoriach potęgi. W konkluzji podkreślono, że odwołujący się do praw naturalnych i odwzorowywany w sformułowaniu ,pokój przez prawo” paradygmat idealistyczny zastąpiła skutecznie użyta dla osiągnięcia założonych celów siła, a środowiska polskiego wychodźstwa nie w pełni dostrzegając jej znaczenie, zbyt optymistycznie odnosiły się do metod rozwiązywania ówczesnych konfliktów, nie zauważając tym samym, że prawo, sprawiedliwość czy też moralność w stosunkach międzynarodowych niewiele zaczęły znaczyć w starciu z realizmem politycznym, którego paradygmat święcił swój wielki triumf.

Slowa kluczowe: konstytucja; integracja europejska; Europa Środkowo-Wschodnia; idealizm polityczny; paradygmat realistyczny; bezpieczeństwo; polska emigracja 


\section{CONSTITUTION OF THE CENTRAL EUROPEAN FEDERATION AS A SIGN OF INTEGRATIONAL IDEALISM \\ IN THE FORMATION OF A REGIONAL SAFETY SYSTEM AS SEEN IN THE POLITICAL VIEWS OF POLISH EMIGRATION IN THE $20^{\mathrm{TH}}$ CENTURY}

\section{S u m m a ry}

During and after the Second World War, representatives of Central and Eastern European nations oppressed by the totalitarian regimes attempted to lobby for alternative projects of Old Continent integration that were to form the basis for discussion on the future of a global safety system after liberating the region from the Soviet domination. In the presented paper, the author describes one of these projects, the Constitution of Central European Federation, in the political and legal context, verifies, on its basis, the hypotheses and the theory of international politics, and tries to answer a question concerning the causes for failure of this proposal for system changes, as well as other options. Considerations follow the definition of the notion of national interest, understood in the categories of power, which helps to read reasons behind actions pursued by various entities. In conclusion, it is emphasised that the idealistic paradigm evoking natural laws and reflected in the expression of "peace through law" was replaced by force used effectively to achieve the set goals, and the Polish emigration milieus were too optimistic about the methods of solving conflicts of that time, without noticing its full meaning and without noticing that law, justice, and morality started to lose their importance in international relations when juxtaposed with political realism whose paradigm had its moment of a great triumph.

Key words: Constitution; European integration; Central and Eastern Europe; political idealism; realistic paradigm; safety; Polish emigration 